\title{
Issues in Measuring An Adjusted Monetary Base
}

\author{
JOHN A. TATOM
}

$\mathrm{T}$

HE Federal Reserve Bank of St. Louis recently announced a new measure of the adjusted monetary base. ${ }^{1}$ Complications arising from the implementation of reserve requirements mandated by the Monetary Control Act of 1980 and changes in the reporting of deposits at financial institutions were responsible for the development of this new adjusted monetary base (AMB) measure.

This article develops an alternative adjusted monetary base measure that empirically implements the concepts developed by Burger and Rasche in $1977 .^{2}$ This alternative measure maintains the previous practice of tying base period reserve requirements, including differential reserve ratios across classes of transactions and time and savings accounts, to those in effect at a past point in time. Although the alternative measure developed here cannot be extended beyond October 1980 for the same reasons that forced the Bank to change its adjusted monetary base measure, this alternative series provides a more exact measure of the old AMB. Consequently, the relationship between the Bank's new AMB series and a series based on the earlier conceptual measure used by this Bank can be assessed more clearly by using the series presented here.

Comparison of the Bank's new adjusted monetary base series prior to November 1980 to the series developed below indicates that there are no significant divergences between movements in the two series.

\footnotetext{
${ }^{1}$ See Alton Gilbert, "Revision of the St. Louis Federal Reserve's Adjusted Monetary Base," this Review (December 1980), pp. 3-10.

${ }^{2}$ The conceptual framework and computational method are explained by Albert E. Burger and Robert $H$. Rasche, "Revision of the Monetary Base," this Review (July 1977), pp.
}

While there are small differences in the two measures, they are of minor importance given the source of the differences and their size.

\section{THE PURPOSE OF THE RESERVE ADJUSTMENT MAGNITUDE}

The money supply process is often analyzed by expressing the money stock (M) as the product of a measure of base money (B) and a money multiplier (m), or

(1) $\mathrm{M}=\mathrm{mB}$.

The multiplier is formulated as:

(2) $\mathrm{m}=\frac{1+\mathrm{k}}{\mathrm{r}+\mathrm{k}}$

where $k$ is the ratio of currency held by the public (excluding vault cash of depository institutions) to their transaction deposits (deposits included in M1B), and $r$ is the average reserve ratio. ${ }^{3}$

Within this framework, the effects of Federal Reserve actions on the money stock can be viewed in two alternative ways. The first is to account separately for actions that directly affect the base and for actions that affect the reserve ratio. The second method adjusts the reserve ratio and base measure so that Federal Reserve actions that affect the money stock are represented only by changes in the monetary base. For example, a decrease in reserve requirements can be viewed as lowering the $r$ ratio, thereby increasing the money stock through an increase in the multiplier. Alternatively, a decrease in reserve requirements lib-

\footnotetext{
3 The reserve ratio is the ratio of total depository institution base holdings to transaction deposits. The ratio includes legal reserve requirement ratios and an excess reserve ratio.
} 
erates reserves and has effects on deposits at financial institutions that are similar to those associated with an increase in the source base. Thus, the impact of a reserve requirement decrease can be isolated in an appropriate increase in a reserve adjustment magnitude (RAM) component of the adjusted monetary base.

The adjusted monetary base is intended to isolate the effects of Federal Reserve actions that affect the money stock in a single summary measure. A useful result of computing a RAM is that the multiplier becomes invariant with respect to changes in legal reserve requirement ratios. In this manner, Federal Reserve actions that influence the money stock are captured in the adjusted monetary base.

\section{THE COMPUTATION OF THE RESERVE ADIUSTMENT MAGNITUDE}

The purpose of a reserve adjustment magnitude is to capture in the adjusted monetary base those total reserve changes that arise from changes in reserve requirements by the Federal Reserve. To do this, the appropriate required reserve holdings are determined through the use of Federal Reserve requirements that existed in an initial (or base) period.

The difference between required reserves computed using base period reserve ratios and actual required reserves is the amount of reserves released or absorbed by changes in Fed reserve requirements since the base period. If current required reserves exceed the amount which would have been required using the base period reserve ratios, then the Fed has "absorbed" reserves, just as it would have through an open market sale of bonds with unchanged reserve requirements.

Consider the simplified representation of the money supply process where the only type of transferable deposit is the bank demand deposit and there is no currency. In addition, suppose that there are reserve requirements only on bank demand deposits and the required reserve ratio $(\mathbf{r})$ is the same for all banks. In this simple example, the money stock (M) equals demand deposits (D), and source base (SB) is held entirely as required reserves for demand deposits at any time ( $t)$, so that $S B_{t}=r_{t} D_{t}$. Consequently, the money stock is:

(3) $\mathrm{M}_{\mathrm{t}}=\mathrm{D}_{\mathbf{t}}=\frac{1}{\mathrm{r}_{\mathrm{t}}} \mathrm{SB}_{\mathrm{t}}$

In this expression, the money stock is the product of the source base and its multiplier. The Fed, however, can change the money stock by changing $r$ (which would change the multiplier) or by changing SB. To capture such changes in a monetary base measure, an adjusted monetary base measure can be constructed so that equation 3 holds in an initial period when the required reserve ratio is $r_{0}$. Subsequent changes in reserve requirements are then viewed as changing deposits and the money stock through changes in the adjusted monetary base. In each period $t$, the adjusted monetary base is defined to be:

(4) $\mathrm{AMB}_{\mathrm{t}}=\mathrm{SB}_{\mathrm{t}}+\left(\mathrm{r}_{\mathrm{o}}-\mathrm{r}_{\mathrm{t}}\right) \mathrm{D}_{\mathrm{t}}=\mathrm{r}_{\mathrm{o}} \mathrm{D}_{\mathrm{s}}$.

The money stock can be expressed as:

(5) $\mathrm{M}_{\mathrm{t}}=\mathrm{D}_{\mathrm{t}}=\frac{1}{\mathrm{r}_{0}} \mathrm{AMB}$

The reserve ratio in the multiplier is now invariant to changes in Fed reserve requirement ratios; it is always $r_{o}$, the reserve ratio in the base period.

Changes in the money stock that arise from Fed required reserve ratio changes are captured by changes in the adjusted monetary base. Specifically, they are captured in the reserve adjustment magnitude:

(6) $\mathrm{AMB}_{\mathrm{t}}=\mathrm{SB}_{\mathrm{t}}+\left(\mathrm{r}_{\mathrm{o}}-\mathrm{r}_{\mathrm{t}}\right) \mathrm{D}_{\mathrm{t}}=\mathrm{SB}_{\mathrm{t}}+\mathrm{RAM}_{\mathrm{t}}$.

If the reserve ratio in period $t\left(r_{t}\right)$ is higher than that in the base period $\left(r_{0}\right)$, reserves have been absorbed and RAM $_{t}$ is negative; if the reserve ratio is lower than in the base period, reserves have been released and RAM $_{t}$ is positive.

This RAM measure is the RAM2 developed by Burger and Rasche. ${ }^{4}$ They note, however, that it has a "practical defect;" it is based on current period deposits $\left(D_{t}\right)$ that are unknown until period $t$ is over. Thus, this measure of the adjusted monetary base would be of limited use for controlling the money stock. Consequently, they introduce an approximation, called RAM3, to measure RAM. In the simple world above, RAM3 is equal to $\left(r_{o}-r_{t}\right) D_{t-1}$. That is, RAM is measured using lagged and, therefore, known deposits.

The RAM3 approximation has been unnecessary, however, at least from 1968 to the present. Under lagged reserve accounting, which has been in effect since 1968, required reserves are computed using

\footnotetext{
4 Burger and Rasche describe three alternative measures of the reserve adjustment magnitude: RAM1, RAM2, and RAM3. RAM 1 is based on the adjustment made by this Bank prior to 1977. RAM2 is an exact measure having the desired theoretical properties of a reserve adjustment magnitude. RAM 3 is an approximation to RAM2 and is the measure prepared by this Bank from 1977 to 1980 . An excellent explanation of the superiority of the RAM2 measure over a measure such as RAM 1 is found in $W . G$. Dewald, "The Monetary Base Adjusted for Required Reserve Ratio Changes," Banca Nazionale Del Lavoro Quarterly Review (December 1979), pp. 407-14.
} 
lagged deposit data. The choice of a base period subsequent to that date leads to a RAM2 concept that uses lagged (known) deposits.

For example, suppose that base period required reserves depend upon deposit levels two weeks earlier. The uses of the source base in the current week t are based upon the required reserve ratio and level of deposits two weeks earlier, or $\mathrm{SB}_{t}=r_{t-2} \mathrm{D}_{t-2}$. Measured relative to current week deposits, current reserves are $r_{t-2}\left(D_{t-2} / D_{t}\right) D_{t}$.

Required reserves using the base period required reserve ratio are $r_{0} D_{t-2}$ or $r_{o}\left(D_{t-2} / D_{t}\right) D_{t}$.

Note that lagged deposits are used to compute base period required reserves since lagged reserve accounting exists in the base period.

Since the uses of the source base must equal its total, $\mathrm{SB}_{\mathrm{t}}=\mathrm{r}_{\mathrm{t}-2}\left(\mathrm{D}_{\mathrm{t}-2} / \mathrm{D}_{\mathrm{t}}\right) \mathrm{D}_{\mathrm{t}}$.

Adding the difference between required reserves in the base period and those in the current week to both sides of this relation yields the adjusted monetary base measure:

(7) $\mathrm{AMB}_{\mathrm{t}}=\mathrm{SB}_{\mathrm{t}}+\left(\mathrm{r}_{\mathrm{o}}-\mathrm{r}_{\mathrm{t}-2}\right) \mathrm{D}_{\mathrm{t}-2}=\mathrm{r}_{\mathrm{o}}\left(\mathrm{D}_{\mathrm{t}-2} / \mathrm{D}_{\mathrm{t}}\right) \mathrm{D}_{\mathrm{t}}$

The money stock $\left(M_{t}=D_{t}\right)$ is then:

(8) $\mathrm{M}_{\mathrm{t}}=\frac{1}{\mathrm{r}_{o}\left(\mathrm{D}_{\mathrm{t}-2} / \mathrm{D}_{\mathrm{t}}\right)} \mathrm{AMB}_{\mathrm{t}}$

Since the source base is determined completely by the Fed and since the RAM is known, the adjusted monetary base measure has the desired properties described by Burger and Rasche. In particular, although RAM is calculated using lagged deposits, it is not an approximation; instead, it is an exact measure if lagged reserve accounting exists in the base period chosen for the RAM measure.

\section{CHANGING THE BASE PERIOD FOR THE ADJUSTED MONETARY BASE}

In the past, the base year used by this bank for computing RAM was arbitrarily set at 1929.5 Since then, several major changes in reserve requirements have occurred. The most sweeping change occurred in

\footnotetext{
5 Actually, the reserve requirements used to compute the base period required reserves for RAM were those in effect from August 1935 to July 1936; accordingly, the old series is labelled in this article as the "adjusted monetary base (1935)." From 1929 to August 1935, reserves were not required on federal govemment deposits at member banks. The changes in the old series (1935) are that RAM is now zero from August 1935 to August 1936 , and not zero from 1929 to 1935 , as originally reported. Data prior to August 1935 are not available at this time.
}

November 1972 when the applicable reserve requirement categories were changed. The previous distinctions among central reserve city, reserve city, and country banks was eliminated and a graduated system of reserve requirements by size of deposits was imposed.

In December 1974, the structure of required reserves on time deposits was changed, again eliminating a distinction used for reserve purposes. Previously, the first $\$ 5$ million of time deposits at a member bank were subject to a 3 percent required reserve ratio and the remainder was subject to a 5 percent ratio. Beginning December 12, 1974, all time deposits became subject to a 3 percent ratio and only $30-179$ day maturity time deposits in excess of $\$ 5$ million were subject to a higher ratio (6 percent). Thus, the structure of reserve requirements changed from one that imposes differential reserve requirements only by size of time deposits to one that imposes a differential by maturity of time deposits (with a size qualification).

There have been other changes in reserve requirements, including additional refinements in deposit categories, but these two instances involve eliminating deposit categories that were previously relevant. In the first instance, demand deposit categories by location were abandoned in 1972. In the second case, a differential reserve requirement on the size of time deposits was abandoned.

The measurement of this Bank's old AMB addressed the structural change in 1972 by employing assumptions about the distribution of demand deposits that proved inappropriate. One method of incorporating these past structural changes, while still consistently measuring the AMB, would be to update the base period for measuring RAM, first in 1972, and again in 1975. The first benchmark period change, to a 1972 base period, results in an $\mathrm{AMB}(1972)$ series. The base period is then updated again beginning in January 1975. The discussion of the first change, to AMB(1972), explains the rationale and procedure for both base period changes.

\section{The 1972 Base Period}

Moving the base period to December 1972 alters the previous calculation of RAM. Reserves released or absorbed by Federal Reserve actions that change reserve requirements after that time are measured relative to the reserve requirements in December 1972 instead of those in 1935. The RAM for demand and time deposits, RAM(1972), is set equal to zero in that month. Thus, in December 1972, the adjusted mone- 
tary base is simply the net source base less reserves absorbed by reserve requirements that are unrelated to either demand or time deposits. These special reserve requirements for Eurodollar borrowings, commercial paper, ineligible acceptances, "over the base period" requirements on certain time deposits, and waiver privileges, averaged $\$ 0.3$ billion (not seasonally adjusted) in December 1972.6 The source base, the total of currency in circulation and bank reserves at Federal Reserve Banks, was $\$ 91.0$ billion. Consequently, AMB(1972) in December 1972 is $\$ 91.3$ billion.

Reserve requirements for member banks from December 1972 to November 1980 are shown in table 1. Changes in reserve requirements subsequent to December 1972 give rise to a RAM adjustment for demand deposits, time deposits, and "other." "Other RAM" measures reserves absorbed by reserve requirements on member banks that are generally unrelated to demand or time deposits.

The computational steps for $\operatorname{RAM}(1972)$, for the period December 1972-January 1975, are:

(1) Determine the distribution of member bank demand and time deposits subject to reserve requirements according to reserve categories two weeks earlier.

(2) For each category of demand deposits, compute required reserves using the current reserve ratio and the ratio in effect in December 1972. If the current required reserve ratio is higher than in December 1972, the difference in required reserves is subtracted from RAM, indicating that reserves have been "absorbed" by reserve requirement changes. If the current ratios are smaller than in December 1972, the entry for this category of deposits is positive, reflecting reserves liberated by reserve requirement changes.

(3) Similarly, compute required reserves on time and savings deposits held two weeks earlier using the base period reserve requirement ratios on time and savings deposits. Subtract the actual required reserves on these deposits to find reserves liberated $(+)$ or absorbed (-) by reserve requirement changes since the base period.

(4) Subtract from RAM all required reserves arising from special reserve requirements, net of waiver privileges.

Item 4 is "other RAM"; this computation is the same as in the construction of the old $\mathrm{AMB}$. Items 2 and 3 differ from the old procedure simply due to the change in the base period. Finally, under the old procedure, vault cash of member banks two weeks earlier was

\footnotetext{
${ }^{6}$ These special reserve requirements are explained in more
} detail by Burger and Rasche, "Revision," pp. 20-21. added to RAM. This step arose because vault cash did not meet reserve requirements during the 1935 base period. Since vault cash satisfied reserve requirements in 1972 and thereafter, this step is unnecessary.

The primary reason for changing the base period is to avoid misrepresenting reserves released or absorbed by reserve requirement changes following the radical change in reserve categories in November 1972. ${ }^{7}$ Measuring the effect of reserve requirement changes relative to reserve ratios and deposit categories adopted in 1972, however, has little or no meaning for the period prior to December 1972; the old measure appropriately measured the growth of the adjusted monetary base prior to the new base period. Consequently, measures of the growth of the adjusted mone tary base before December 1972 have not been altered by changing the base period. This poses a problem, however, since the level of the adjusted monetary base in December 1972 (1935 base period) is $\$ 88.6$ billion, while the amount measured relative to the 1972 base period is $\$ 91.3$ billion.

To provide comparable measures of the growth of the adjusted monetary base both before and after the 1972 change in the structure of deposit categories requires "chaining" the two series together in December 1972, resulting in the adjusted monetary base (1972) series. ${ }^{8}$ This method of computing the adjusted monetary base with a 1972 base period leaves unchanged the measured growth rate of the earlier adjusted monetary base series for the period prior to the new base period.

Consider the expression for a monetary aggregate in equation 1. Prior to 1972 , the old RAM used in calculating the monetary base equals the difference between required reserves computed using 1935 ratios and actual required reserves. The relevant reserve ratios in the multiplier, $m$, are those in 1935. The change to a 1972 base period changes once and for all the reserve ratios entering the multiplier to those in effect in December 1972. Thus, in December 1972 the adjusted monetary base, $\mathrm{B}$, is raised by a proportion, $\mathrm{p}$ $(\mathrm{p}=1.0312)$, to equal the source base less special

\footnotetext{
7 The problems of constructing RAM following a change in the deposit classification system used for reserve purposes are discussed in Appendix 2

${ }^{8}$ In December 1972 , AMB(1972) is 3.12 percent larger than AMB(1935). To preserve the growth rate of the adjusted monetary base (not seasonally adjusted) up to December 1972 , the monthly data (1935) are increased by this percentage for each month to obtain AMB(1972). Prior to this adjustment, $A M B(1935)$ was changed to reflect the actual reserve accounting practice in the base period (1935), rather than computing RAM on lagged deposits.
} 


\section{Table 1}

\section{Member Bank Reserve Requirements}

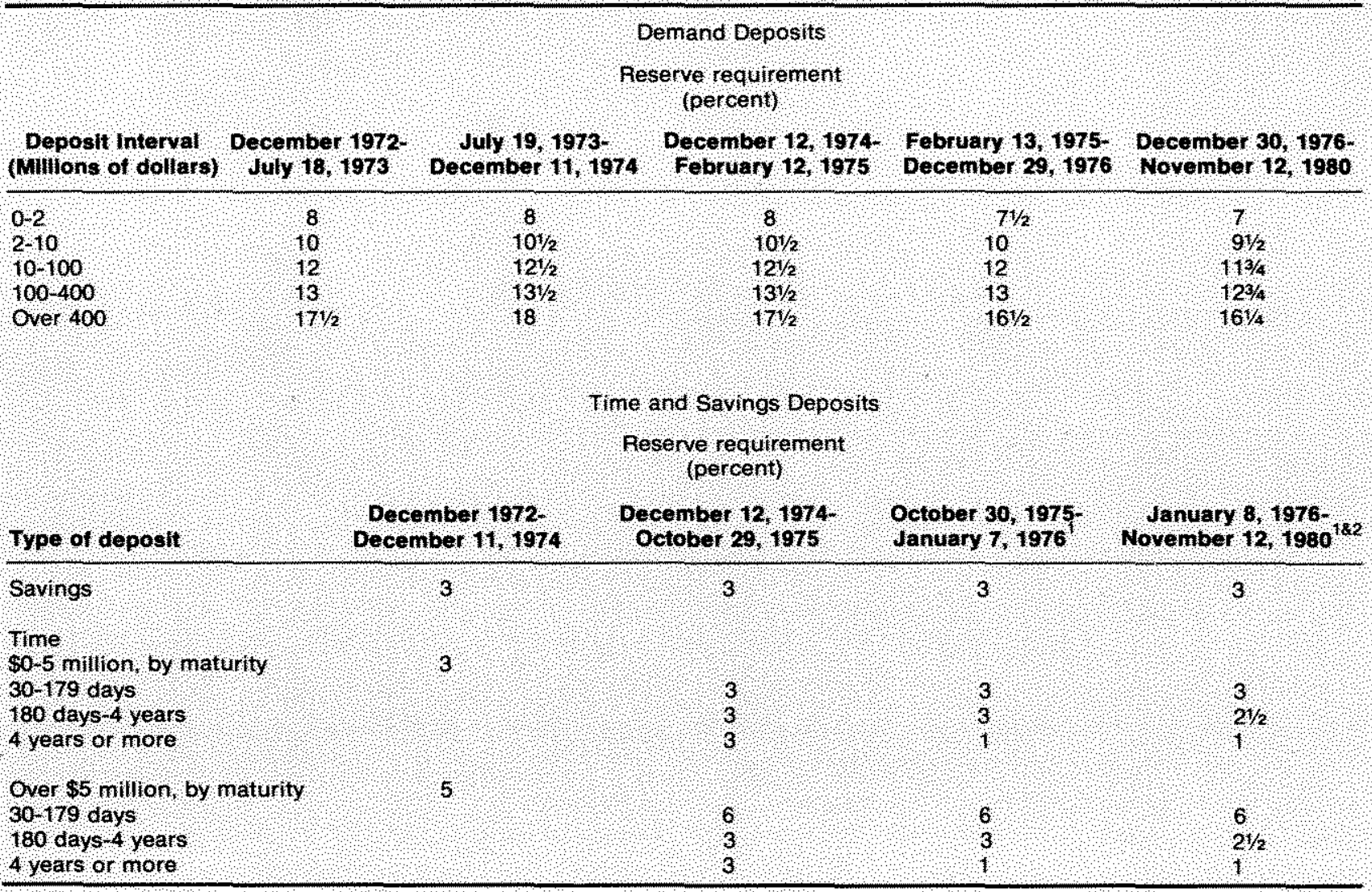

Subject to mimmin of 3 percent of total time and saving deposits.

Thme deposits greater than $\$ 100,000$ are subject to a 2 percent supplemental resenve reguirement for deposits held from the week ending November 8,1978 to the week ending July 16,1080

reserve requirements. To provide comparable data prior to December 1972, the 1935 base period series (not seasonally adjusted) is raised by the same constant. In effect the multiplier, $m$, is reduced by $(1 / p)$ times its original level. Although the levels of both the multiplier and the base in the period prior to December 1972 are altered, the relationship between percentage changes in each and percentage changes in any monetary aggregate is unaffected. Thus, empirical relationships between growth of the adjusted monetary base and monetary aggregates are unaffected by the method of rebasing RAM. ${ }^{9}$

\footnotetext{
${ }^{9}$ Growth rates measured across the month in which the base is changed depend on growth up to that month and growth since then. The level of the AMB is measured exactly relative to the base period in effect at each point in time and the method of chaining the series together makes the levels of the $\mathrm{AMB}$ measure comparable so that growth rates are maintained.
}

\section{The 1975 Base Period}

The structure of required reserves on time deposits changed in December 1974, eliminating a distinction used for assessing differential reserve requirements in the December 1972 base period (table 1). From December 1972 to December 1974, differential reserve requirements were imposed according to the size of time deposits. Subsequently, differential reserve requirements were imposed only according to the size of the time deposits in the 30-179 day maturity category. Thus, some time deposits of other maturities were no longer subject to a differential ratio. ${ }^{10}$

\footnotetext{
I0 In October 1975 and in January 1976 reserve requirements on time deposits were changed so that deposits of various maturities were subject to different ratios. These new maturity distinctions changed required reserve ratios on deposits subject to the basic 3 percent ratio in the January 1975 base period, but these changes did not eliminate any part of the structure in existence in Jantary 1975
} 


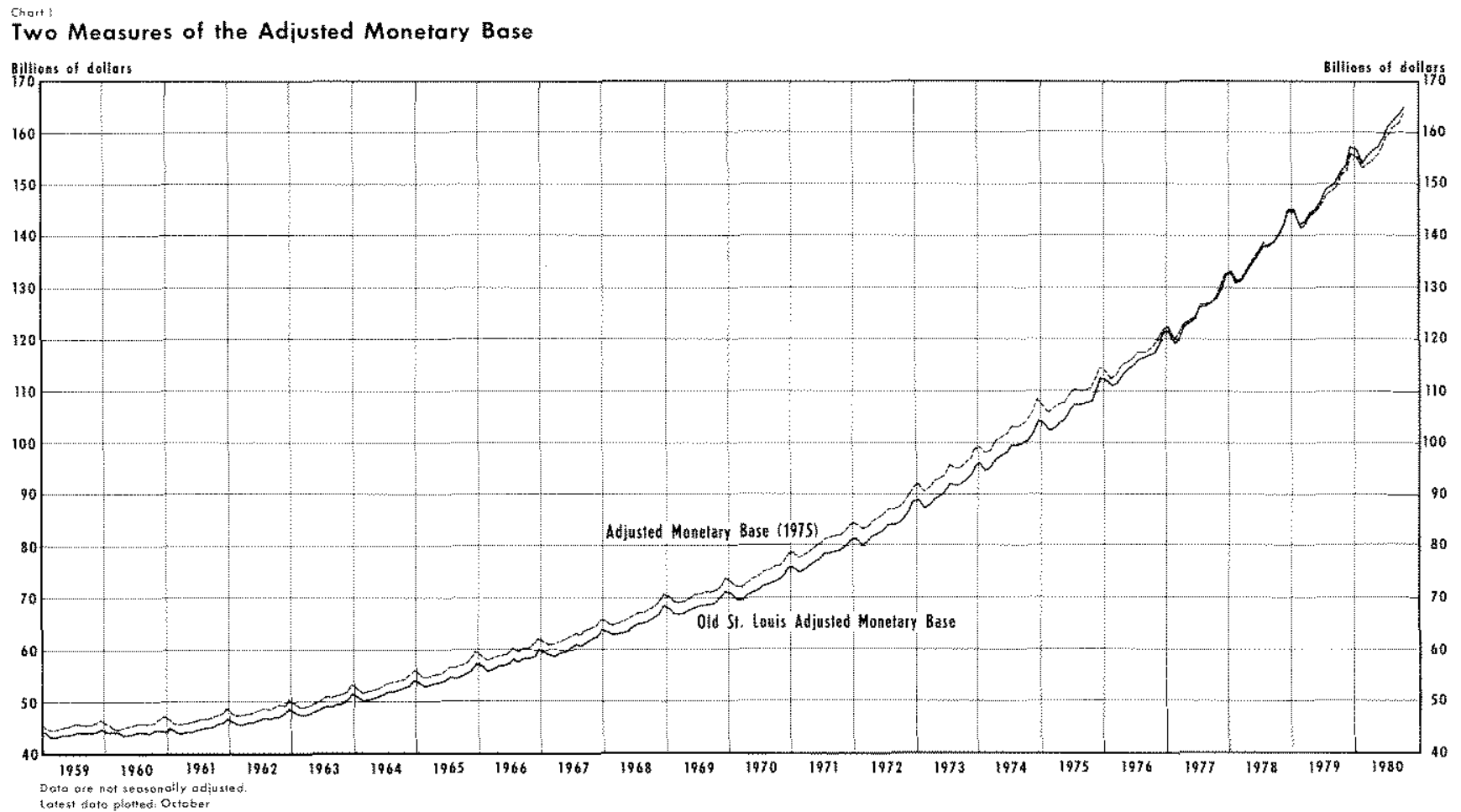

The January 1975 base period adjusted monetary base series is computed in precisely the manner described above, including the computation of $A M B(1972)$ and $A M B(1975)$ for January 1975 so that the prior data can be appropriately adjusted to be compatible with AMB(1975) measures after January 1975. In January 1975, AMB(1972) is $\$ 106.8$ billion while source base plus "other RAM," AMB $(1975)$ is $\$ 107.2$ billion. Consequently, prior data for AMB(1975) are constructed by multiplying $\mathrm{AMB}(1972)$ by the ratio (107.2/106.8). The complete monthly series for $\operatorname{AMB}(1975)$ is shown in Appendix 1.

\section{Measuring Adjusted Bank Reserves with a Changing Base Period}

The alternative AMB series described above has one property that is a significant departure from other AMB series. The AMB (1975) data prior to January 1975 are appropriately viewed as indices of the adjusted monetary base. Consequently, currency in the hands of the non-bank public cannot simply be deducted from the AMB series to obtain an "adjusted bank reserves" series prior to January 1975. In rebasing an AMB series, the rebased data prior to a new base period are a constant multiple of the old data.

To obtain an adjusted bank reserve series that is compatible with the adjusted monetary base data developed here requires using the same rebasing methods for both series. For example, consider an adjusted bank reserves series which uses January 1975 as the base period. In January 1975, adjusted bank reserves equal the actual bank reserves less special reserve requirements. In subsequent months, adjusted bank reserves (1975) are the adjusted monetary base (1975) less currency in the hands of the non-bank public, as is the case for adjusted bank reserves (1935) from 1935 to November 1972, or for adjusted bank reserves (1972) from December 1972 to January 1975. In order to find the adjusted bank reserves (1975) for dates prior to January 1975, however, the adjusted bank reserve (1972) data must be chained together using the same method as used for rebasing the adjusted monetary base. The data then are comparable across the base period changes, and the history of adjusted bank reserve growth is unchanged. Adjusted bank reserves (1975) data are given in Appendix 3.

\section{COMPARISON OF THE OLD ST. LOUIS ADJUSTED MONETARY BASE AND $\mathrm{AMB}(1975)$}

Charts 1 and 2 present a comparison of the old and 1975 base period adjusted monetary bases and their 
Eharg ?

M1B Multipliers

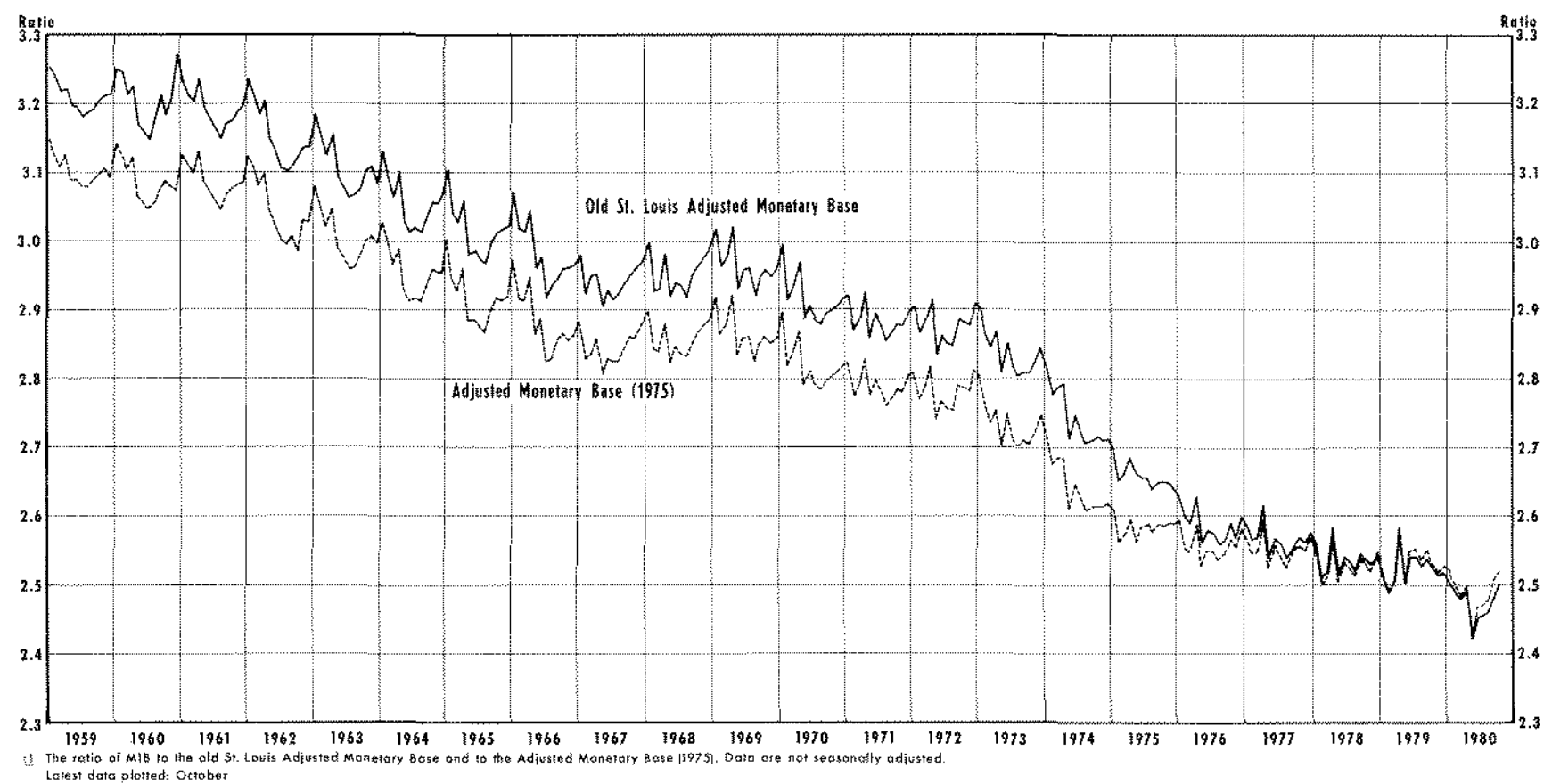

associated M1B-multipliers for the period January 1959 to October 1980. From 1959 to 1972 , there is little variation in the difference between the adjusted monetary base series. From January 1959 to December 1972, AMB(1975) exceeds the old measure by an average of $\$ 2.0$ billion. The standard deviation of this difference is $\$ 0.4$ billion. From December 1972 to October 1980, the difference varies more. For this period, AMB(1975) exceeds the old AMB by $\$ 1.2$ billion on average, but the standard deviation of this difference is $\$ 1.8$ billion. The level of $\mathrm{AMB}(1975)$ differs little from the old measure after 1975.

As indicated in chart 2, the multiplier associated with AMB(1975) varies less than that of the old series. From January 1959 to December 1972, the mean and standard deviation of the old M1B multiplier are 3.032 and 0.121 , respectively. For the same period, the mean M1B multiplier (1975) is 2.932 with a standard deviation of 0.115 . The difference during this period primarily reflects the level adjustment of the old adjusted monetary base to a new base period. Nonetheless, other minor changes in this period reduce the standard deviation by a relatively larger amount than the decline in the mean. From December 1972 to October 1980, the mean of the old multiplier drops sharply to 2.622 and the standard deviation is 0.119 .
The mean of the 1975 series drops less sharply to 2.587. The standard deviation of 0.078 is smaller than that for the old series in this period.

The coefficient of variation, the ratio of the standard deviation of a variable to its mean, of the multiplier using $\mathrm{AMB}(1975)$ is lower in the December 1972 to October 1980 period than during the January 1959 to December 1972 period $(0.030$ and 0.040 , respectively). The coefficient of variation of the old multiplier rose from 0.040 prior to December 1972 to 0.046 since December 1972.

Chart 3 shows growth rates for four-quarter periods for the old AMB and AMB(1975). There is essentially no difference between these growth rates until the beginning of 1975. After that time, technical problems in the measurement of the old AMB resulted in an overstatement of base growth, especially in 1975. The mean difference in the growth rates of the old $A M B$ and $A M B(1975)$ in chart 3 from $I / 1959$ to $I V / 1974$ is 0.003 percent and the standard deviation of this difference is only 0.28 percent. Subsequently, the old $A M B$ grows at an average four-quarter growth rate that is 0.80 percentage points larger than that of $\mathrm{AMB}(1975)$. The standard deviation of this difference more than doubles to 0.58 percentage points. 
chors 3

Comparison of Growth Rates:

Old St. Louts Adjusted Monetary Base and Adiusted Monetary Base (1975) a

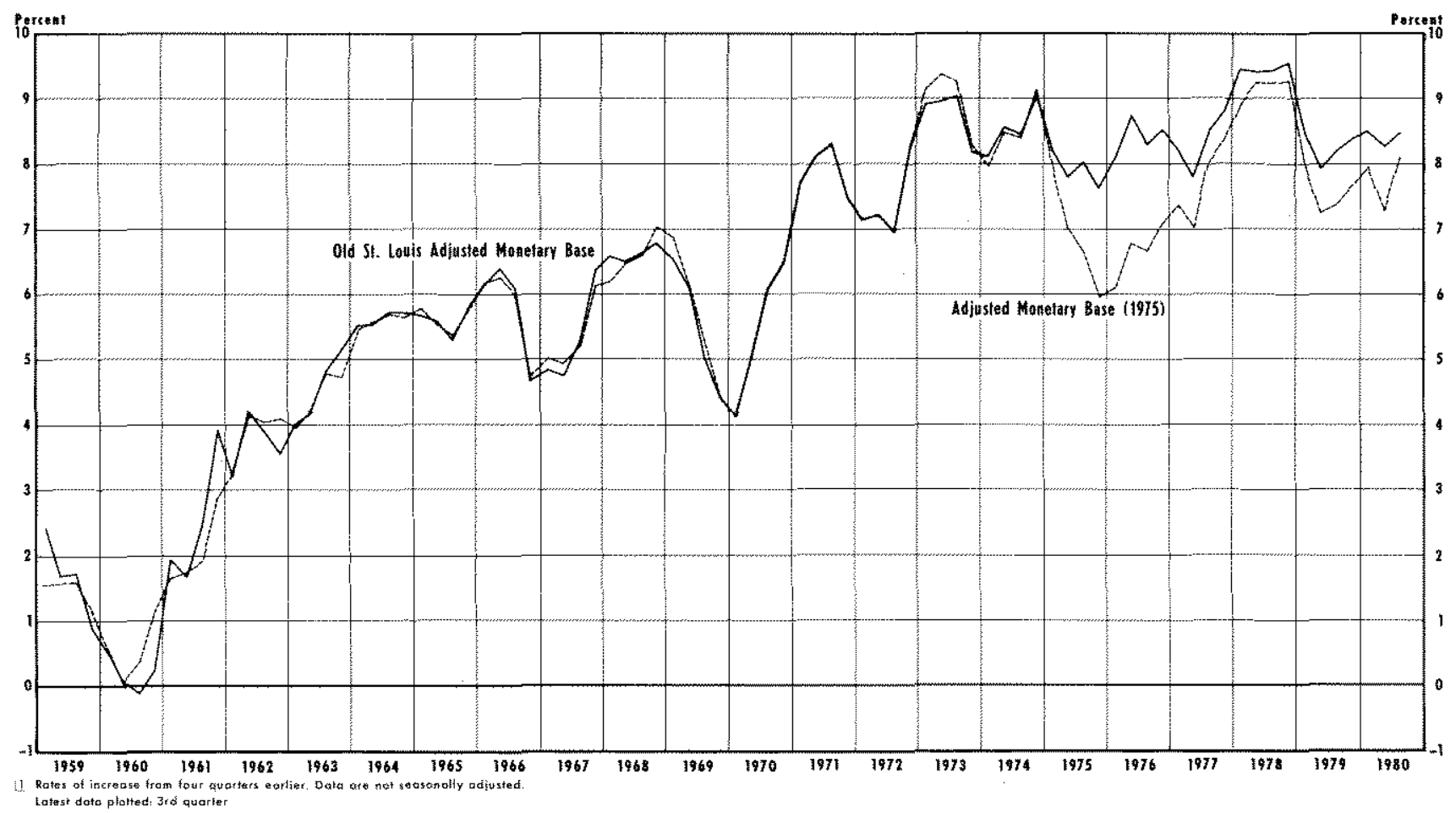

COMPARISON OF THE NEW ST,LOUIS ADIUSTED MONETARY BASE AND $\mathrm{AMB}(1975)$

The principal difference between the new $A M B$ calculated by this Bank and AMB(1975) lies in the base period required reserve ratios. For $\mathrm{AMB}(1975)$, the ratios are set at levels existing in January 1975, so that the RAM for demand deposits and time and savings deposits is zero in that month. In the new measure, the base period required reserve ratios are not tied to a particular point in time. Since the selected average reserve ratios for member bank transaction deposits and time and savings deposits need not equal the levels that existed in any particular month, the RAM on these deposits need not be zero in any month.

A second difference is that changes in differential reserve requirements do not result in the same type of RAM adjustment with the new AMB measure as with either the Bank's previous $A M B$ or $A M B(1975)$. The required reserve ratios that enter the multiplier under the new measure are fixed average ratios. With the old measure and $\mathrm{AMB}(1975)$, these ratios are weighted averages of the fixed required reserve ratios, where the weights are proportions of deposits in each class of deposits. The latter are determined by changes in market shares of financial institutions in different deposit classifications. Consequently, changes in the proportions of deposits subject to differential reserve requirements affect monetary aggregates through changes in the multiplier in the AMB(1975) framework, while the effect of these changes is captured in AMB movements using this Bank's new measure.

Chart 4 shows the annual growth rates of the Banks new $A M B$ and $A M B(1975)$ for four-quarter periods from 1959 to 1980 . The two series grow at the same average rate of 5.9 percent over the whole period. The standard deviation of the growth rate of both series over the period shown in chart 4 is the same, 2.4 percent. The standard deviation of the difference in growth rates is only 0.5 percent. The largest differences occur after 1972, when differential reserve requirements across deposit categories became more numerous.

The largest difference in chart 4 occurs in 1975, when the new AMB grows faster than AMB(1975). 
Chort A

Comparison of Growth Rates:

New St. Louis Adjusted Monetary Base and Adjusted Monetary Base (1975):

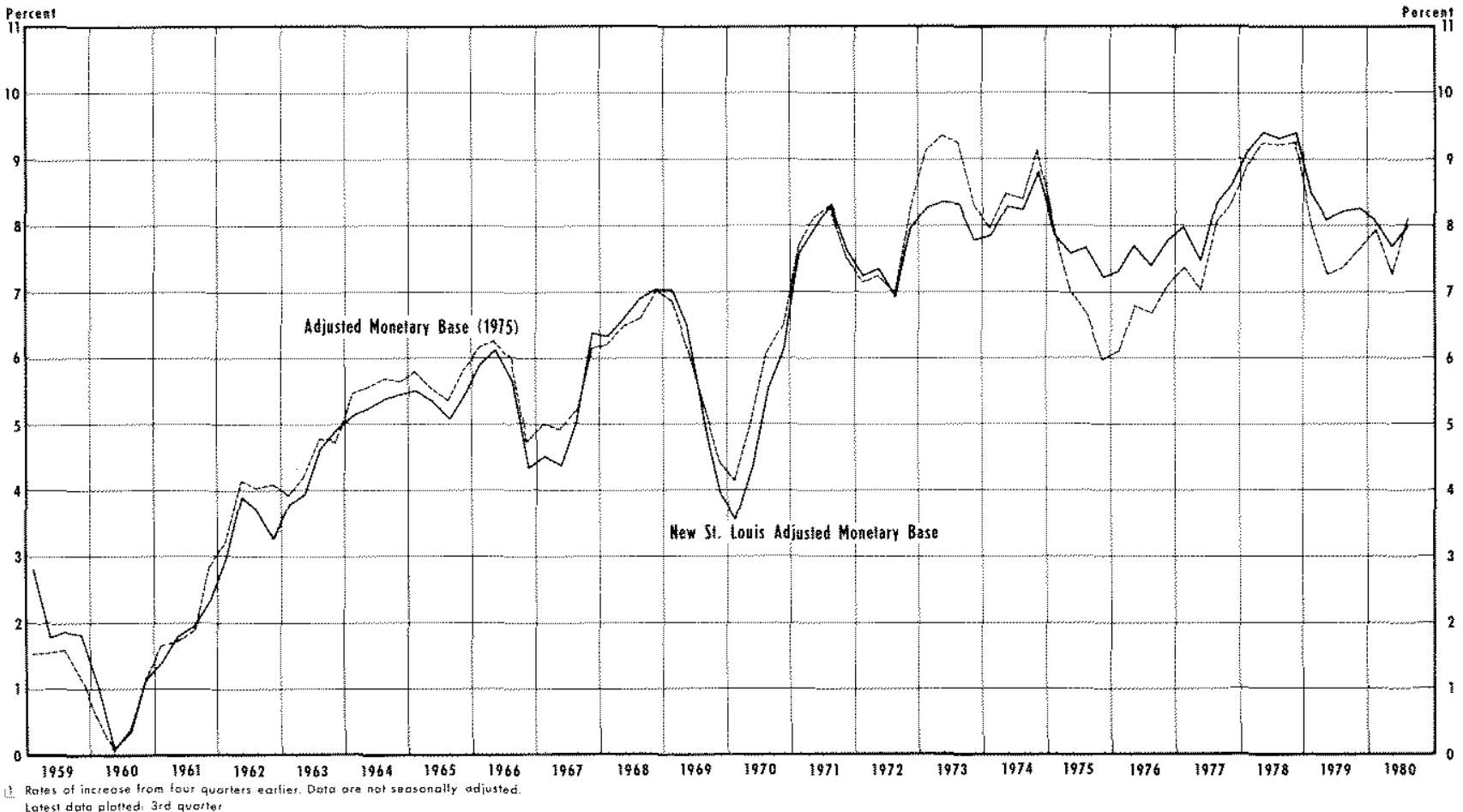

Growth of the Bank's new AMB decreases to a 7.2 percent rate during the year ending in the fourth quarter of 1975 , from 8.8 percent in the prior year. This decline is smaller than the 3.1 percentage point drop in the growth of AMB(1975) during the same period. The difference in the growth of the new AMB and $A M B(1975)$ in 1975 arises because the addition to RAM due to reserve requirement decreases on demand deposits in February 1975 and on some time deposits in November and December 1975 has a bigger percentage effect on the new AMB than on AMB (1975). At the end of 1974, the Bank's new RAM is large and negative. The release of reserves in 1975 had a larger impact on the Bank's new AMB than it did on either the source base or $\mathrm{AMB}(1975)$.

The difference in the growth rates of the two adjusted monetary bases arises during different periods for several distinct reasons. The differences in the growth rates to the fourth quarter of 1972 reflect the differences in the treatment of vault cash in the two series. Also, over this period, deposit shifts occurred that would increase the rratio, calculated with 1935 base period requirements. These shifts are accounted for in the new AMB by slightly slower AMB growth. From the fourth quarter of 1968 to the fourth quarter of 1972, the differences in growth rates are small; the new AMB grows at a 6.4 percent annual rate while AMB(1975) grows at a 6.7 percent rate (the same as that for the old $\mathrm{AMB}$ measure).

When deposit shifts occur across deposit categories with differential reserve requirements in the base period, the required reserve ratio in the multiplier changes. If this ratio is not allowed to vary, as in the new AMB measure, the AMB measure itself must adjust to reflect the effect that would otherwise have occurred in the multiplier. Thus, when deposit shifts occur that would raise (lower) the required reserve ratio computed using some actual base period ratios, the Bank's new AMB will grow slower (faster) than a measure such as that developed here. An example of this occurs from the fourth quarter of 1972 to the first quarter of 1975 , when increases in the proportions of demand deposits at larger institutions would tend to raise the required reserve ratio on demand deposits 
computed with the required reserve ratios in effect in December 1972. During this period, AMB $(1975)$ rose at a 7.9 percent annual rate while the new $A M B$ rose at a 7.5 percent rate. From the first quarter of 1975 to the third quarter of $1980, \mathrm{AMB}(1975)$ grew at a 7.8 percent rate, slightly slower than the 8.3 percent growth rate of the new measure. This difference arises from deposit shifts during the period which lowered those ratios computed using the required reserve ratios in effect in January 1975. To insulate the $r$ ratio in the multiplier for the Bank's new measure from the effects of such deposit shifts on the required reserve ratio, the new AMB measure must grow slightly faster.

The new AMB is less than AMB(1975) from January 1959 to October 1980 by an average of $\$ 2.1$ billion. This simply reflects the higher average required reserve ratio in January 1975 than that in the "base period" used to construct the new AMB. The standard deviation of this difference is $\$ 1.2$ billion. From December 1972 to October 1980 the $\mathrm{AMB}(1975)$ exceeds the new AMB by an average of $\$ 3.3$ billion and this difference has a standard deviation of only $\$ 0.7$ billion. Measured in percentage differences, the new AMB averages 2.6 percent less than $\mathrm{AMB}(1975)$ from January 1959 to October 1980; the standard deviation of this difference is 0.9 percent. Since December 1972 , the percentage difference is 2.9 percent and the standard deviation of the difference is 1.0 percent. These results indicate that the new AMB measure is very similar to AMB(1975). Moreover, the largest differences arise during periods when the structure of reserve requirements is characterized by numerous differential reserve requirements across classes of deposits. Under the Monetary Control Act of 1980, the number of classes of deposits subject to differential requirements will narrow sharply. Thus, the Bank's new AMB should be even closer to an alternative AMB measure constructed in the manner presented here.

\section{CONCLUSION}

This article describes a procedure for calculating an adjusted monetary base that completely captures the effects of significant changes in the structure of reserve requirements that occurred in 1972 and 1975. This procedure avoids inappropriate assumptions concerning deposit structure and some other technical pitfalls associated with the adjusted monetary base previously published by this Bank.

To extend the alternative AMB measure developed here beyond October 1980 would require another base period change because of the phase-out of deposit categories that were subject to differential reserve requirements in January 1975 . In addition, information on required reserves for new deposit categories would be necessary. Unfortunately, this information is simply not available, and it is doubtful that it could become available on a timely basis in the future.

These complications arise from the implementation of the reserve requirements mandated by the Monetary Control Act of 1980 and have necessitated the development of the new adjusted monetary base prepared by this Bank. This new measure has considerable appeal due to its computational simplicity when compared with the previously published series or the measure developed here. Moreover, the Bank's new $A M B$ series and the AMB $(1975)$ series described in this article display similar growth patterns for the period prior to November 1980. This demonstrates that the new series published by this Bank should continue to provide a useful summary measure of Federal Reserve actions that influence the money stock.

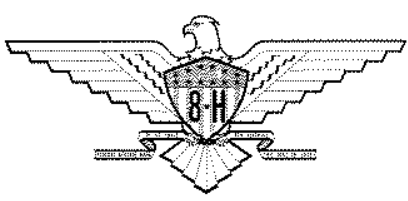




\section{Appendix 1}

This Appendix contains data for the adjusted monetary base discussed in this article. Table 1 provides the adjusted monetary base for three periods, based upon different base periods applying over each interval. Table 2 is the adjusted monetary base ( 1975 base period) measure constructed for the period $1936-1980$. Table 3 provides seasonally adjusted measures of $\mathrm{AMB}(1975)$.

Table 1

Adjusted Monetary Base (billions of dollars, not seasonally adjusted)

\begin{tabular}{|c|c|c|c|c|c|c|c|c|c|c|c|c|}
\hline Year & January & $\begin{array}{l}\text { Feb- } \\
\text { ruary }\end{array}$ & March & Aptil & May & June & July & August & $\begin{array}{c}\text { Septem- } \\
\text { ber }\end{array}$ & $\begin{array}{l}\text { Octo- } \\
\text { ber }\end{array}$ & $\begin{array}{l}\text { Novem } \\
\text { ber }\end{array}$ & $\begin{array}{l}\text { Decem- } \\
\text { ber }\end{array}$ \\
\hline \multicolumn{13}{|c|}{1935 Base Period } \\
\hline 1936 & 11.5 & 116 & 113 & 112 & 116 & 115 & 113 & 109 & 11, & 11,4 & 117 & 117 \\
\hline 1937 & 116 & 108 & 108 & 102 & 104 & 10.3 & 10.3 & 102 & 10,4 & 106 & 10,6 & 10.6 \\
\hline 1938 & 107 & 106 & 111 & 117 & 119 & 121 & 125 & 124 & 125 & 129 & 132 & 13.3 \\
\hline 1939 & 134 & 13.3 & 134 & 141 & 14.5 & 14.6 & 14.9 & 152 & 160 & 16.5 & 16.4 & 16.3 \\
\hline 1940 & 16.7 & 16.8 & 170 & 174 & 178 & 18.4 & 187 & 18.4 & 187 & 19.2 & 19.4 & 19.6 \\
\hline 1941 & 19.7 & 19.5 & 195 & 193 & $19: 5$ & 19.3 & 19,4 & 19.4 & 198 & 187 & 18.8 & 191 \\
\hline 1942 & 19.3 & 19.4 & 19.5 & 19.4 & 19.5 & 19.9 & 200 & 20.9 & 216 & 21.9 & 22.6 & 23.6 \\
\hline 1943 & 23.9 & 23.9 & 24,4 & 24,4 & 243 & 24.7 & 25.2 & 257 & 26.5 & 26.3 & 270 & 27.8 \\
\hline 1944 & 281 & 28.0 & 28.3 & 287 & 294 & 303 & 30.3 & 30,6 & 314 & 322 & 332 & 33.4 \\
\hline 1945 & 33.5 & 337 & 343 & 345 & 352 & 35.7 & 356 & 361 & 36.7 & 371 & 375 & 37.9 \\
\hline 1946 & 37.5 & 37.1 & 369 & 369 & 370 & 373 & 375 & 37.5 & 37.7 & 378 & 38.1 & 38.5 \\
\hline 1947 & 379 & 37.4 & 374 & $37: 3$ & 37.3 & 37.5 & 37.6 & 376 & 38,3 & 38.4 & 38.3 & 38.8 \\
\hline 1948 & 38.4 & 372 & 37.4 & 371 & 36,8 & 37.1 & 37.4 & 36.8 & 36.4 & 377 & 37.8 & 38.0 \\
\hline 1949 & 375 & 369 & 36,8 & 377 & 368 & 37.5 & 379 & 379 & 37,1 & 371 & 371 & 37.5 \\
\hline 1950 & 37.2 & 36,6 & 367 & 36.5 & 36.5 & 36.7 & 36.8 & 36.7 & 37,1 & 37.3 & 37.4 & 37.5 \\
\hline 1951 & 36.4 & 372 & 374 & 375 & 37,3 & 37.9 & 38.1 & 38.1 & 38.5 & 39.0 & 39.1 & 40.0 \\
\hline 1952 & 39.6 & 390 & 392 & 38.9 & 39.0 & 39.5 & 39.9 & 39.8 & 40.3 & 40.4 & 40.9 & 41,7 \\
\hline 1953 & 410 & 40.6 & 40.5 & 40.3 & 40,4 & 417 & 413 & 411 & 41.3 & 414 & 41.6 & 42,1 \\
\hline 1954 & 417 & 409 & 40,8 & 407 & 409 & 41.6 & 421 & 412 & 412 & 41.6 & 420 & 42.5 \\
\hline 1955 & 417 & 41,2 & 41, & 41,2 & 412 & 414 & 417 & 416 & 418 & 41.9 & 42.2 & 429 \\
\hline 1956 & 42.2 & 415 & 41,7 & 41,6 & 41,6 & 420 & 42.2 & 42.0 & 423 & 42.3 & 42.8 & 43.6 \\
\hline 1957 & 427 . & 42.0 & 42.0 & 42,1 & 42.0 & 42.4 & 42.7 & 42.4 & 42.6 & 42,6 & 42.8 & 43.7 \\
\hline 1958 & 42.8 & 42.7 & 428 & 42.8 & 428 & 43.2 & 43.5 & 43.4 & 43.4 & 43.4 & 438 & 447 \\
\hline 1959 & 43.8 & 43,3 & 432 & 43.4 & 43.6 & 43.8 & 44.2 & 44.1 & 44,1 & 44.1 & 443 & 45,1 \\
\hline 1960 & 44.3 & 43.4 & 43,3 & 435 & 43.6 & 43.8 & 44.2 & 443 & 44,4 & 44.4 & 44.9 & 45.7 \\
\hline 1961 & 44.9 & 44.2 & 44.1 & 44.2 & 44.3 & 44.7 & 45.0 & 45.1 & 453 & 45.6 & 46.2 & 470 \\
\hline 1962 & 46.4 & 45.5 & 45.7 & 460 & 46.2 & 46.5 & 47.0 & 46.9 & 47.0 & 47.9 & 47.8 & 48.8 \\
\hline 1963 & 48.0 & 47.4 & 47.6 & 479 & 481 & 48.5 & 49.2 & 49.1 & 49.4 & 496 & 50.2 & 51.6 \\
\hline 1964 & 507 & 49,9 & 502 & 505 & 507 & 51.4 & 51.8 & 519 & 52.3 & 52.5 & 53.1 & 54.2 \\
\hline 1965 & 53.6 & 52.9 & 53.1 & 534 & 53.5 & 54,1 & 54.7 & 54.7 & 550 & 55.5 & 561 & 57.5 \\
\hline 1966 & 56,9 & 56,2 & 56.3 & 56.9 & 57.0 & 57.2 & 58.2 & 57.8 & 58.2 & 58.2 & 58,8 & 601 \\
\hline 1967 & 59.6 & 590 & 59.3 & 59.5 & 59.7 & 60.4 & 610 & 60.9 & 61,4 & 618 & 625 & 637 \\
\hline 1968 & 63.4 & 626 & 62.8 & 63,3 & 63.6 & 64.3 & 65,1 & 65.0 & 65,4 & 660 & 66.8 & 68.4 \\
\hline 1969 & 68.0 & 67.0 & 669 & 67.1 & 67.7 & 68.1 & 68,4 & 68.6 & 68.7 & 690 & 69.9 & 71,2 \\
\hline 1970 & 70.8 & 69.7 & 69.7 & 70.5 & 71.1 & 71.6 & 72.4 & 72.6 & 73.2 & 736 & 743 & 759 \\
\hline 1971 & 75.9 & 75.1 & 75.4 & 76.1 & 76.9 & 77.4 & 78.7 & 78.7 & 79.0 & 79.2 & 80.0 & 813 \\
\hline 1972 & 81.4 & 80.3 & 80.8 & 818 & 824 & 83.0 & 84.3 & 84.2 & 84.3 & 853 & 866 & 886 \\
\hline \multicolumn{13}{|c|}{1972 Base Period } \\
\hline 1972 & & & & & & & & & & & & 91.3 \\
\hline 1973 & 917 & 90.2 & 91.1 & 92.4 & 92.9 & 93.4 & 95.4 & 94.7 & 94.8 & 95.6 & 96.6 & 98.5 \\
\hline $\begin{array}{l}1974 \\
1975\end{array}$ & $\begin{array}{r}990 \\
1068\end{array}$ & 97.7 & 98.1 & 100.1 & 100.9 & 101.4 & 103.0 & 102.7 & 103,1 & 104.0 & 105.5 & 107.8 \\
\hline \multicolumn{13}{|c|}{1975 Base Period } \\
\hline 1975 & 1072 & 105.8 & to6.5 & 107,5 & 107.6 & 109.6 & 110.2 & 110.0 & 110.1 & 110.5 & 112.3 & 1145 \\
\hline 1976 & 113.5 & 112. & 113.3 & 114.9 & 115.6 & 116.2 & $\$ 17.4$ & 117.4 & 117.6 & 118.5 & 1205 & 122.3 \\
\hline 1977 & 122.5 & 120.1 & 121.3 & 123.1 & 123.6 & 124.4 & 126.8 & 126.8 & 127.0 & 128.5 & 130.2 & 132.7 \\
\hline 1978 & 133,1 & 131.3 & 131.9 & 133.9 & 135.1 & 136.4 & 138.6 & 138.2 & 138.9 & 140.6 & 142.4 & 144.6 \\
\hline 1979 & 144.5 & 141.5 & 142.2 & 144.2 & 144.7 & 146,0 & 148.3 & 148.6 & 149.4 & 151.6 & 1527 & 156.0 \\
\hline 1980 & 155,3 & 152.9 & 154.0 & 154.4 & 155.1 & 157,0 & 159.9 & 160.9 & 1618 & 163.5 & - & - \\
\hline
\end{tabular}


Table 2

Adjusted Monetary Base, 1975 Base Period (billions of dollars, not seasonally adjusted)

\begin{tabular}{|c|c|c|c|c|c|c|c|c|c|c|c|c|}
\hline Year & January & rebs & March & April & May & June & Jaly & August & Septem - & Oeto & $\begin{array}{l}\text { Novern } \\
\text { ber }\end{array}$ & Decem \\
\hline 1936 & 11,9 & 120 & 117 & 116 & 120 & 119 & 117 & 113 & 115 & 118 & 121 & 121 \\
\hline 1937 & 12.0 & 112 & 112 & 10.6 & $10 \%$ & 107 & 107 & 10.6 & 10.8 & 10.9 & 109 & 110 \\
\hline 1938 & 110 & 110 & 11,5 & 121 & 123 & 126 & 129 & 12.8 & 13,0 & 13.4 & 13,6 & 137 \\
\hline 1939 & 13,8 & 13.7 & 139 & 146 & 150 & 151 & 15,4 & 157 & 166 & 170 & 16.9 & $16 \%$ \\
\hline 1940 & 172 & 174 & 176 & 18.0 & 18.4 & 190 & 19.3 & 190 & 19.4 & 199 & 201 & 203 \\
\hline 1941 & 20.4 & 20.1 & 202 & 200 & 20.2 & 200 & 201 & 201 & 20.5 & 19,4 & 19.4 & $19 \%$ \\
\hline 1942 & 20.0 & 20.1 & 202 & 201 & 20.2 & 206 & 207 & 21.7 & 22.4 & 22,6 & 23.4 & 24.4 \\
\hline 1943 & 24.7 & 247 & 253 & 253 & 251 & 25,6 & 261 & 26.6 & 274 & 272 & $27 \%$ & 20.7 \\
\hline 1944 & 29. & 29.0 & 293 & 297 & 304 & 31.3 & 313 & 317 & 325 & 33.3 & 34.4 & 34.5 \\
\hline 1945 & 34.6 & 34.9 & 354 & 35.7 & 36.4 & 369 & 36.8 & 374 & 38.0 & 38.3 & 38.8 & 392 \\
\hline 1946 & 38.8 & 38.3 & 38.2 & 38.2 & 38.3 & 38.6 & 38.8 & 38.8 & 390 & 39,1 & 39,4 & 39.8 \\
\hline 1947 & 392 & 38.7 & 307 & 38.6 & 38.6 & 387 & 38,9 & 38.9 & 39.6 & 397 & 39.6 & 40.2 \\
\hline 1948 & 39.7 & 36.5 & 38,7 & 38.4 & 38.0 & 384 & 387 & 381 & 377 & 39.0 & 391 & 39.4 \\
\hline 1949 & 38.8 & 382 & 38.1 & $39: 0$ & 381 & 38.8 & 39.2 & 39.3 & 384 & 38.4 & 38.4 & 38.8 \\
\hline 1950 & 38.4 & $37 \%$ & 37.9 & 37.8 & 37.8 & 38.0 & 38 & 37.9 & 38.3 & 38.5 & 38,6 & 38.8 \\
\hline 1951 & 377 & 384 & 38.7 & 38.8 & 38.6 & 392 & 39.4 & 39.4 & 39.8 & 40.4 & 40.5 & 413 \\
\hline 1952 & 410 & 40.4 & 40.6 & 40.3 & 404 & 40,9 & 41,2 & 41,2 & 416 & 418 & 42.3 & 43.1 \\
\hline 1953 & 42.4 & 41.9 & 4199 & 417 & 417 & 432 & 428 & 425 & 427 & 42.8 & 43.1 & 43.6 \\
\hline 1954 & 43.1 & 423 & 42.2 & 421 & 42.4 & 430 & 43.5 & 426 & 427 & 430 & 43.5 & 43.9 \\
\hline 1955 & 43.2 & 42.6 & 425 & 42.6 & 42.6 & 428 & 431 & 43.1 & 43.2 & 43,4 & 43.7 & 44.4 \\
\hline 1956 & 43.7 & 43.0 & 432 & 43. & 431 & 435 & 43,6 & 43.5 & 43.8 & 438 & 443 & 451 \\
\hline 1957 & 44.2 & 43,4 & 434 & 43.6 & 43,4 & 43,8 & 44,2 & 439 & 44 & 441 & 443 & 45,2 \\
\hline 1958 & 44,2 & 44.2 & 44,3 & 44.3 & 442 & 44.7 & 450 & 449 & 44.9 & 449 & 45.3 & 46.2 \\
\hline 1959 & 453 & 447 & 44,7 & 449 & 45. & 45.3 & 457 & 45.6 & 45.6 & 45.6 & 45.8 & 46.6 \\
\hline 1960 & 45.8 & 44.9 & 44,8 & 45.0 & 45. & 45, & 45.8 & 45.8 & 45.9 & 45,9 & 46.4 & 47.2 \\
\hline 1961 & 46.5 & 45.7 & 45.6 & 45.7 & 45.8 & 462 & 46.5 & 46.6 & 46.9 & 47.2 & 477 & 48.6 \\
\hline 1962 & $47 \%$ & 471 & 47.2 & 476 & 47.8 & 48,1 & 48.6 & 48.5 & 48,6 & 49.6 & 49.4 & 50.5 \\
\hline 1963 & 49.7 & 490 & 492 & 495 & 498 & 50.2 & 509 & 507 & 510 & 513 & 519 & 53.4 \\
\hline 1964 & 52,5 & 516 & 51.9 & 52.2 & 52.4 & 531 & 536 & 53.7 & 541 & 543 & 550 & 56,1 \\
\hline 1965 & 554 & $54: 8$ & 54.9 & 55.3 & 55.3 & 56.0 & 56.6 & 56.6 & 56.9 & 57.4 & 58,1 & 59.5 \\
\hline 1966 & 58.8 & 581 & 582 & 58.8 & 590 & 592 & 6022 & 59.8 & 602 & 602 & 60.9 & 62,1 \\
\hline 1967 & 61,6 & 61.1 & 613 & 61.5 & 61.8 & 624 & 631 & 63.0 & 63.5 & 64,0 & 647 & 65.8 \\
\hline 1968 & 65,6 & $64: 8$ & 650 & 65.5 & 65.8 & 66.5 & 673 & 672 & 67.6 & 68.3 & 69, & 707 \\
\hline 1969 & 70.3 & 69.3 & 692 & 69.4 & 70.0 & 70.4 & 707 & 710 & 710 & 713 & 723 & 737 \\
\hline 1970 & 73.2 & 721 & 721 & 729 & 73.6 & 74,0 & 749 & 75,1 & 75.7 & 76.1 & 76.8 & 78.5 \\
\hline 1971 & 78.5 & 777 & 78.0 & 787 & 79.6 & 80, & 814 & 814 & 817 & 81.9 & 828 & 84, \\
\hline 1972 & 842 & 83.1 & 836 & 84.6 & 85.2 & 85,8 & 872 & 871 & 87.2 & 88.2 & 89.6 & 915 \\
\hline 1973 & 920 & 90.5 & 91,4 & 927 & 93.2 & 93,7 & 957 & 95,0 & 95,0 & 95,9 & 96.9 & 98.8 \\
\hline 1974 & 99,3 & 98.0 & 98.4 & 100,4 & 101,2 & 1017 & 103.3 & 1030 & 1034 & 104.3 & 105.8 & 100.2 \\
\hline 1975 & 1072 & 1058 & 106.5 & 1075 & $107: 6$ & 109,6 & 1102 & 110.0 & 110,1 & 110,5 & 1123 & 114,5 \\
\hline 1976 & 1135 & 121 & 113,3 & 1149 & 115,6 & 162 & 174 & 1174 & 1176 & 118.5 & 1205 & 1223 \\
\hline 1977 & 1225 & 120. & 121,3 & 123,1 & 123.6 & 124,4 & 126,8 & 126.8 & 1270 & 128.5 & 1302 & 1327 \\
\hline 1978 & 1331 & 131,3 & 1319 & 1339 & 1351 & 136.4 & 138.6 & 1382 & 1389 & 1406 & 1424 & 1446 \\
\hline 1979 & 1445 & 1415 & 1422 & 1442 & 1447 & 1460 & 1463 & 148,6 & 149.4 & 1516 & 1527 & 1560 \\
\hline 1980 & 155,3 & 1529 & 154.0 & 154.4 & 1551 & 157.0 & 159.9 & 1609 & 1618 & 1635 & 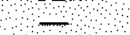 & 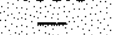 \\
\hline
\end{tabular}




\section{Table 3}

\section{Adjusted Monetary Base, 1975 Base Period} (bilitions of dollars, seasonally adjusted)

\begin{tabular}{|c|c|c|c|c|c|c|c|c|c|c|c|c|}
\hline Year & January & $\begin{array}{l}\text { Feb- } \\
\text { Ftary }\end{array}$ & March & April & May & June & July & August & Septen & oeto & $\begin{array}{l}\text { Novem } \\
\text { ber }\end{array}$ & $\begin{array}{l}\text { Decem } \\
\text { ber }\end{array}$ \\
\hline 1936 & 118 & 12,3 & 118 & 118 & 119 & 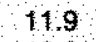 & 117 & 11,4 & 115 & 116 & 119 & 119 \\
\hline 1937 & 119 & 114 & 113 & 108 & 107 & 10.6 & 107 & 107 & 108 & 108 & 10.8 & 10.8 \\
\hline 1938 & 109 & 112 & 116 & 123 & 123 & 125 & 128 & 129 & 129 & 132 & 134 & 136 \\
\hline 1939 & 138 & 140 & 140 & 148 & 15.0 & 151 & 153 & 158 & 166 & 169 & 16.8 & 167 \\
\hline 1940 & 171 & 176 & 177 & 182 & 185 & 191 & 19.3 & 191 & 19,3 & 198 & 200 & 201 \\
\hline 1941 & 203 & 203 & 203 & 201 & 203 & 200 & 201 & 202 & 20,4 & 193 & 19.3 & 19.5 \\
\hline 1942 & 19.8 & 202 & 202 & 203 & 203 & 207 & 20.8 & 217 & 222 & 22,6 & 233 & 24,0 \\
\hline 1943 & 244 & 247 & 25,3 & 255 & 25,4 & 25,7 & 26.3 & 267 & 273 & 271 & 278 & 26.2 \\
\hline 1944 & 287 & 290 & 293 & 299 & 307 & 315 & 316 & 318 & 323 & 332 & 34 & 339 \\
\hline 1945 & 34,3 & 350 & 35,6 & 360 & 368 & $37 \times 1$ & 371 & 376 & 378 & 382 & 36.4 & 38.4 \\
\hline 1946 & 38.4 & 38,5 & 38.4 & 386 & 387 & 388 & 390 & 390 & 389 & 389 & 389 & 390 \\
\hline 1947 & 389 & 390 & 390 & 390 & 390 & 389 & 39.0 & 39.1 & 395 & 39,4 & 392 & 394 \\
\hline 1948 & $39 / 4$ & 38,8 & 390 & 388 & 38,5 & 385 & 387 & 383 & 376 & 388 & 387 & 386 \\
\hline 1949 & 385 & 38.5 & 383 & 394 & 386 & 389 & 392 & 394 & 383 & 382 & 380 & 380 \\
\hline 1950 & 382 & 382 & 38, & 382 & 383 & 38,1 & 38,0 & 381 & 383 & 383 & 383 & 38.1 \\
\hline 1951 & 374 & 388 & 38.9 & 39.2 & 391 & 393 & 39.4 & 396 & 398 & 402 & 401 & 40.5 \\
\hline 1952 & 407 & 407 & 409 & 407 & 406 & 41.0 & 412 & 41,4 & 416 & 41,6 & 419 & 422 \\
\hline 1953 & 422 & 423 & 422 & 422 & 422 & 432 & 427 & 427 & 427 & 426 & 427 & 426 \\
\hline 1954 & 429 & 426 & 42.6 & 426 & 428 & $43 /$ & 43,4 & 428 & 426 & 42,9 & 431 & 429 \\
\hline 1955 & 429 & 430 & 429 & 43.1 & 43,1 & 429 & 43.1 & 432 & 431 & 433 & 433 & 433 \\
\hline 1956 & 434 & 43,4 & 436 & 435 & 43,5 & 435 & 435 & 436 & 437 & 437 & 439 & 440 \\
\hline 1957 & 439 & 439 & 439 & 440 & 439 & 439 & 440 & 439 & 44,0 & 440 & 430 & 441 \\
\hline 1958 & 440 & 44.6 & 44.8 & 447 & 44,7 & 449 & 448 & 449 & 448 & 449 & 45,0 & 451 \\
\hline 1959 & 450 & 452 & 45.2 & 45.4 & 45.5 & 455 & 45.6 & 456 & 45,6 & 455 & 455 & 45,5 \\
\hline 1960 & 45.5 & 45.4 & 45,4 & 45.4 & 455 & 45,5 & 45.6 & 45,8 & 459 & 459 & 46,1 & 460 \\
\hline 1961 & 461 & 462 & 462 & 46.2 & 462 & 464 & 4644 & 467 & 468 & $47 /$ & 473 & 47.4 \\
\hline 1962 & 476 & 47.6 & 478 & 48.1 & 482 & 483 & 485 & 486 & 486 & 495 & 490 & 492 \\
\hline 1963 & 493 & 496 & 498 & 50.0 & 50,3 & 50.4 & 508 & 500 & 510 & 51,1 & $51 \%$ & 520 \\
\hline 1904 & 521 & 52,3 & 525 & 527 & 530 & 533 & 535 & 538 & 541 & 542 & 545 & 546 \\
\hline 1965 & 550 & 55.4 & 55.5 & 55.8 & 559 & 562 & 56.4 & 56,7 & 569 & 573 & 57.6 & 58.0 \\
\hline 1966 & 58,4 & 58.7 & $58: 9$ & 59.3 & 59.6 & 594 & $60 ; 1$ & 600 & 60.1 & 60.2 & 60.4 & 60.6 \\
\hline 1967 & 611 & 61.6 & 620 & 620 & 623 & 626 & 629 & 63.2 & 636 & 640 & 642 & 644 \\
\hline 1968 & 65.1 & 653 & 65.7 & 660 & 66,3 & 66.7 & 671 & 67.4 & 67.8 & 683 & 688 & 69.1 \\
\hline 1969 & 697 & 69.8 & 69.8 & 70.0 & 70.7 & 70.6 & 70.6 & 713 & 71,2 & 714 & 719 & 72.0 \\
\hline 1970 & 724 & 72.6 & 72.9 & 73.5 & 74.2 & 742 & 74,8 & 75.4 & 75.9 & 76.1 & 763 & 768 \\
\hline 1971 & 77.6 & 78.3 & 789 & 79.3 & 800 & 80,4 & 812 & 816 & 819 & 820 & 822 & 824 \\
\hline 1972 & 83.4 & 838 & 846 & 853 & 856 & 861 & 869 & 872 & 873 & 884 & 892 & 89.8 \\
\hline 1973 & 910 & $91 \times 3$ & 92.3 & 933 & 93.5 & 94.0 & 95.1 & 95.0 & 954 & 962 & 966 & 972 \\
\hline 1974 & 982 & 98.9 & 99.4 & 1009 & 1014 & 1019 & 102.5 & 103,1 & 1037 & 1047 & 105.6 & 106.6 \\
\hline 1975 & 1060 & 1069 & 107,6 & 107.7 & 107.7 & 109.9 & 109.5 & 1102 & 110.8 & 1110 & 1120 & 112.5 \\
\hline 1976 & 1123 & 113.5 & $\because 14.3$ & $1+5$ & 1157 & 116.5 & 1167 & 117.6 & 1183 & 119 & 120.0 & 120.2 \\
\hline 1977 & 121.3 & 121,6 & 1224 & 123,3 & 1239 & 1247 & 126.1 & 1270 & 1278 & 129 & 129.5 & 130.4 \\
\hline 1978 & 131.6 & 133,1 & 1333 & 1342 & 135.5 & 136.6 & 137.8 & 138.4 & 397 & 1410 & 446 & 142,4 \\
\hline 1979 & 1428 & 1434 & 1439 & 144.7 & 1454 & 146.4 & 147.5 & 148.9 & 150 & 1517 & $5+8$ & 153.2 \\
\hline 1980 & 153.4 & 1549 & 155.8 & 1550 & 155.9 & 1575 & 1591 & 161.1 & 1625 & 1636 & $\therefore$ & . \\
\hline
\end{tabular}




\section{Appendix 2}

\section{The Structure of Deposit Classes and the Reserve Adjustment Magnitude}

In the fall of 1972, the deposit categories for reserve requirements on demand deposits were changed. This change altered the criterion for determining required reserve assessments on demand deposits as well as their growth rates. Prior to this change, a member bank's required reserve ratio on demand deposits depended upon its location-whether the bank was a central reserve city bank, reserve city bank, or country bank. Since then, a bank's required reserve ratio has been determined only by its size. This change has implications for the reserve adjustment magnitude (RAM) which are taken into account in the measures presented in the text. The purpose of this appendix is to describe the difference between the old RAM and RAM(1975) to illustrate these implications.

The central distinction between the old RAM and RAM(1972) for the period since November 1972 concerns the effect of a changing distribution of demand deposits among member banks on reserves released or absorbed due to differential reserve requirements. In particular, the old RAM assumes that net deposit growth occurs in a manner so as to preserve the distribution of deposits by size and location that existed in 1972. Reserve requirements on net demand deposits in November 1972 were lower than in 1935 for banks with up to $\$ 27$ million of net demand deposits in New York and Chicago and for banks with up to $\$ 12$ million in other reserve cities. For all other banks, required reserve ratios were higher in November 1972 than in 1935, and the difference escalated with the size of the bank. The net effect on old RAM was that reserves had been absorbed by a net increase in reserve requirements on member bank net demand deposits since 1935. More importantly, however, given the difference in reserve requirements across banks, changes in the distribution of deposits affected the reserves absorbed by the new requirements.

For example, after November 1972 a movement of net demand deposits away from member banks in New York and Chicago to those in other reserve cities or outside of reserve cities would tend to liberate reserves based on the 1935 criterion for assessing reserve burdens. Under the reserve regime existing in December 1972 , a $\$ 100$ net demand deposit movement from a large Chicago or New York member bank to a small member bank outside of a reserve city would free $\$ 3.50$ in reserves and this amount would be added to an exact RAM (1935). This would occur because the $\$ 100$ withdrawal in New York would have been subject to a 13 percent reserve requirement in 1935 and 17.5 percent in 1972 so the reserve adjustment $(.130-.175)(-\$ 100)$ is $\$ 4.50$. The $\$ 100$ deposit in the country bank is subject to an 8 percent requirement in 1972, but would have been subject to a 7 percent requirement in 1935 , resulting in a reserve adjustment of $(.07-.08)(\$ 100)$, or $-\$ 1.00^{1}$

\footnotetext{
${ }^{1}$ Note that if the Fed had raised reserve requirements on the country bank by an identical amount as on the New York bank
}

The old RAM after 1972 is based on an approximation that assumes the distribution of net demand deposits by size and location remains fixed. Thus, in the example above, deposits would be assumed to leave New York in proportion to the ratios of net demand deposits in New York held by each size class during November 1972 , and to be deposited in country banks in proportion to the distribution of country banks in November 1972. Based on the proportions of New York and Chicago net demand deposits held by banks in deposit categories \$0-2 million, $\$ 2-10$ million, $\$ 10-100$ million, $\$ 100-400$ million, and over $\$ 400$ million, 13 cents of the $\$ 100$ net demand deposits moved would be drawn from the first size class, 53 cents from the second, $\$ 5.97$ from the third, $\$ 16.00$ from the fourth, and $\$ 77.37$ from the last. The required reserves on this $\$ 100$ in New York are $\$ 16.40$ in December 1972 compared with $\$ 13.00$ in 1935 . The $\$ 100$ deposit in country banks is distributed among the size classes as $\$ 15.11$ in $\$ 0-2$ million banks, $\$ 30.81$ in $\$ 2-10$ million banks, $\$ 42.45$ in $\$ 10$-100 million banks, $\$ 11.23$ in $\$ 100-400$ million banks, and 40 cents in country banks with over $\$ 400$ million in deposits. The required reserve on these deposits is $\$ 10.91$, compared with $\$ 7.00$ in 1935 . The reserve release in computing old RAM is the reserve adjustment on the deposit withdrawal, $-(\$ 13.00-\$ 16.40), \$ 3.40$ phus the reserve adjustment on the new deposit $(\$ 7.00-\$ 10.91),-\$ 3.91$, so that the old RAM would show a 51 cent reduction in the adjusted monetary base. Given the distribution of deposits in November 1972 , the new reserve regime reflects a larger increase in reserve requirements for country banks (from 7 percent to 10.91 percent) than for New York and Chicago banks (13 percent to 16.4 percent). For the deposit movement from New York to the smallest class country bank, the old RAM would overstate the exact addition to the adjusted monetary base by $\$ 4.51$ or 4.51 percent of the size of the deposit movement.

The distribution of deposits has changed since 1972. For computation of old RAM, the distribution of deposits in November 1972 was assumed to remain the same. Compara. ble data for November 1979 show that there has been a shift of deposits away from New York and Chicago banks. These banks held 21.0 percent of net demand deposits in November 1972 and 19.4 percent in November 1979. The largest part of this shift was to banks in other reserve cities whose share rose from 35,3 percent to 36.5 percent. The share of country banks rose from 43.7 percent in November 1972 to 44.1 percent in November 1979. The old RAM computed on these net demand deposits in November 1979 is $-\$ 6.6$ billion. An exact measure of the difference between reserves required using 1935 ratios and those in effect on these deposits in

(from .07 to .1150 ) the change in distribution would have neither absorbed ror freed reserves. Distributional changes affect RAM only when the distribution of reserve burdens on deposits has been changed by required reserve ratio changes subsequent to the base period. 
November 1979 is $-\$ 7.0$ billion. The approximation used in the computation of the old RAM leads to an overstatement of the adjusted monetary base by $\$ 0,4$ billion for this period.

The most important point, however, is that following a change in the method of assessing reserve burdens, such as from ratio differences arising from location to ratio differences arising from size, the distributional changes that should be allowed to change the adjusted monetary base are altered. The old reserve regime (1935) reflected a decision to have required reserves altered by deposit movements by location. When reserve ratios were altered differentially across locations, the Fed mandated that reserve requirem ments change (relative to the base period) whenever the distribution of deposits by location changed and, until 1972, these reserve requirement changes were exactly measured in RAM.

Subsequent to November 1972, however, changes in the distribation of deposits by location could lead to changes in required reserves that no longer reflected the effect of actions of the Federal Reserve. By changing the criterion for assessing reserve burdens from location to size, such movements can be viewed as a matter of indifference to the Fed as far as reserve requirements are concerned. After November 1972, reserve burdens were assessed on the basis of size only. It then became questionable whether changes in required reserves that would have arisen from locational shifts reflected a monetary policy action by the Federal Reserve.

For example, if the distribution of deposits across size classes remained the same from 1972 to the present, but the share of deposits in New York and Chicago fell, how should the adjusted monetary base change? The average required reserve ratio on net demand deposits held in November 1972 , using the reserve ratios in effect later in that month, was 16.40 percent for New York and Chicago banks, 14.27 percent in other reserve city banks and 10.91 percent for country banks. Relative to 1935 requirements, (13 percent, 10 percent, and 7 percent respectively), reserve ratios had been increased most for other reserve city banks and country banks. Thus, the movement of deposits away from Chicago and New York would be comparable to an open market operation which absorbed reserves. Under the new reserve regime, required reserves would be unaffected by such a distributional change. A reduction in the AMB (1935) would represent the effects of reserve ratio changes due to distributional changes that were no longer considered relevant by the Federal Reserve. By changing the base period to December 1972 , such changes in locational distribution would have no effect on the adjusted monetary base.

To illustrate the difference between the old RAM and RAM(1972 and 1975) due to changing the base period, consider reserve requirements imposed on a twomay classification of a single type of deposit $D$, in period zero with required ratios $r_{10}, r_{20}$ levied on each class $D_{A}$ and $D_{B}$, respectively $\left(D=D_{A}+D_{B}\right)$. In period $j$, deposits are divided in classes $D_{C}$ and $D_{D}\left(D=D_{C}+D_{D}\right)$ with required reserve ratios initially set at $r_{1}^{*}, r_{2 j}^{*}$, respectively. In each case, the first subscript for the r-ratio refers to a deposit class and the second subscript refers to a period of time. In this example, the reserve ratio $\mathrm{f}_{1 \mathrm{t}}$ could apply in major cities at time $t$, while $r_{2 t}$ applies to demand deposits at all other banks. In period 1, demand deposits are classified differently, e.g., by

\section{Table 1}

\section{A Simple Change in a Two-Way Classification of Deposits for Reserve Purposes}

\begin{tabular}{|c|c|c|c|c|}
\hline retial base period, reserve ratio on deposits & & 10 & 920 & Sun of \\
\hline Newratio & r & 0 & D. & D. \\
\hline Ondeposits & 1, & 0 & D. & O. \\
\hline sum of columns & & o. & D. & D \\
\hline
\end{tabular}

size, so that $\mathrm{x}$ if initially applies to the first $\$ 25$ million of demand deposits at an institution, while $r$ applies to demand deposits over $\$ 25$ million, regardless of location. Subsequent to period $\mathrm{j}$, the ratios $\mathrm{r}(\mathrm{i}=1,2)$ can be changed but the classification system is fixed (i.e., under and over $\$ 25$ million).

The change in classification systems can be represented by the matrix in table 1. Deposits are divided into four groups $\mathrm{D}_{1}$ through $\mathrm{D}_{4}$. The initial reserve classification imposes reserve requirements on $D_{A}\left(D_{1}\right.$ and $\left.D_{3}\right)$ through the common reserve ratio $r_{1}$ and on deposits $D_{B}\left(D_{2}\right.$ and $\left.D_{4}\right)$ through $r_{2}$. In period $i$, the classification system changes so that deposits in group 1 and 2 have a common ratio $r$, while deposits in groups 3 and 4 have a common ratio r 2 . From an initial base period zero to period $j$, the $R A M$ is $\mathbf{R A M}_{\mathrm{t}}=\left(\mathrm{r}_{10}-\mathrm{r}_{1 \mathrm{t}}\right) \quad\left(\mathrm{D}_{1}+\mathrm{D}_{3}\right)+\left(\mathrm{r}_{20}-\mathrm{r}_{2 \mathrm{t}}\right) \quad\left(\mathrm{D}_{2}+\mathrm{D}_{4}\right)$ where deposits are those in the period for which RAM is calculated. Following the change in the classification system in period $\mathrm{j}$, in period $t+j$, the old RAM could be calculated relative to the base period zero as:

$$
\begin{aligned}
\text { RAM }_{t+j} & =\left(r_{10}-r_{1+j}^{*}\right) D_{1}+\left(r_{10}-r_{2}^{*} t+j\right) D_{3} \\
& +\left(r_{20}-r_{t+j}^{*}\right) D_{2}+\left(r_{20}-r_{2}^{*} t+j\right) D_{4} .
\end{aligned}
$$

This expression can be rearranged by adding and subtracting terms expressing required reserves on the new classification at the point of its introduction, $j$ :

$$
\begin{aligned}
\mathrm{RAM}_{\mathrm{t}+\mathrm{j}} & =\left(\mathrm{r}_{10}-\mathrm{r}_{1 \mathrm{j}}\right) \mathrm{D}_{1}+\left(\mathrm{r}_{\mathrm{j}}-\mathrm{r}_{\mathrm{t}+\mathrm{j}}\right) \mathrm{D}_{1} \\
& +\left(\mathrm{r}_{10}-\mathrm{r}_{2 \mathrm{j}}\right) \mathrm{D}_{3}+\left(\mathrm{r}_{2 \mathrm{j}}-\mathrm{r}_{\mathrm{t}+\mathrm{j}}\right) \mathrm{D}_{3} \\
& +\left(\mathrm{r}_{20}-\mathrm{r}_{1 \mathrm{j}}\right) \mathrm{D}_{2}+\left(\mathrm{r}_{1 \mathrm{j}}-\mathrm{r}_{\mathrm{t}+\mathrm{j}}\right) \mathrm{D}_{2} \\
& +\left(\mathrm{r}_{20}-\mathrm{r}_{\mathrm{j}}\right) \mathrm{D}_{4}+\left(\mathrm{r}_{\mathrm{i}}-\mathrm{r}_{\mathrm{t}+\mathrm{j}}\right) \mathrm{D}_{4}
\end{aligned}
$$

If one wished to measure reserves released or absorbed by reserve requirement changes since period j relative to period ij reserve requirements, the appropriate expression, RAM $^{*}+$, would be the four entries on the extreme right above,

$$
\mathrm{RAM}_{\mathrm{i}+\mathrm{j}}^{*}=\left(\mathrm{r}_{\mathrm{j}}^{*}-\mathrm{r}_{\mathrm{t}+\mathrm{j}}^{*}\right)\left(\mathrm{D}_{\mathrm{I}}+\mathrm{D}_{2}\right)+\left(\mathrm{r}_{2 \mathrm{j}}^{*}-\mathrm{r}_{\mathrm{2}}^{*} \mathrm{t+ \textrm {j }}\right)\left(\mathrm{D}_{3}+\mathrm{D}_{4}\right)
$$

rearranging the components of $\mathrm{RAM}$ in the column immediately to the right of the equal sign above results in the expression: 


$$
\begin{aligned}
\mathbf{R A M}_{t+j} & =\left[r_{10}\left(\frac{D_{1}}{D_{1}+D_{2}}\right)+r_{20}\left(\frac{D_{2}}{D_{1}+D_{2}}\right)-r_{1 j}^{*}\right]\left(D_{1}+D_{2}\right) \\
& +\left[r_{10}\left(\frac{D_{3}}{D_{3}+D_{4}}\right)+r_{20}\left(\frac{D_{4}}{D_{3}+D_{4}}\right)-r_{2 j}^{*}\right]\left(D_{3}+D_{4}\right) \\
& + \text { RAM }_{++j}^{*} .
\end{aligned}
$$

This expression for RAM differs from the one developed following the old RAM procedure used by this Bank for demand deposits in only one important respect. "Effective base period required reserve ratios" for the sums $\left(D_{1}+D_{2}\right)$ and $\left(\mathrm{D}_{3}+\mathrm{D}_{4}\right)$ in the expression above depend on the distribution of deposits in period $(t+j)$, while the old RAM procedure freezes the proportions in parentheses in such an expression at the proportions in the period when the structure changed (November 1972).

Under the initial reserve structure the effect of a change in the share $\left(D_{1} /\left(D_{1}+D_{2}\right)\right)$ on required reserves should be included in RAM because the Fed recognized the distinction between $D_{1}$ and $D_{2}$ type deposits by imposing a different reserve requirement ratio on each. Beginning in period $j$, the Fed imposed the same reserve ratio on $D_{1}$ and $D_{2}$, so there is no effect of movements between them on required reserves. It makes little sense to make a RAM change to reflect a Fed action based upon a Fed criterion that was abandoned in period $\mathrm{j}$.

In order to capture the effects of Federal Reserve actions that change reserve requirements in the adjusted monetary base, the base period for computing RAM can be changed whenever the classification system for imposing reserves is changed in a manner that eliminates distinctions relevant in the base period. Such a change in the classification system occurred for demand deposits in November 1972, when required reserve differences due to location were abandoned. A second change in structure occurred in December 1975 when reserve requirements on time deposits were altered so that differential requirements were imposed by maturity category rather than by size. The Monetary Control Act of 1980 also mandates such a change beginning in 1980 . A broad set of differential reserve requirements by size of deposits will be compressed to two classes of deposits. 


\section{Appendix 3}

This appendix provides data for adjusted bank reserves. In table 1, adjusted bank reserves for three periods, based upon the different base periods applying over each interval, are presented. Adjusted bank reserves in each case is the source base minus currency in the hands of the public, and minus the RAM measure computed relative to the indicated base period. In table 2, these data are provided on a continous, 1975 base period, basis. In this table, aljusted bank reserves prior to January 1975 are not equal to the adjusted monetary base (1975) less currency. Instead the data reflect the growth of adjusted bank reserves in each prior interval based upon the relevant base period, but the levels are adjusted so that they are comparable to the post-1974 levels.

Table 1

Adjusted Bank Reserves (billions of dollars, not seasonally adjusted)

\begin{tabular}{|c|c|c|c|c|c|c|c|c|c|c|c|c|}
\hline Year & January & $\begin{array}{l}\text { Feb- } \\
\text { ruary }\end{array}$ & March & AprII & May & June & July & August & Septem & $\begin{array}{l}\text { Octo- } \\
\text { ber }\end{array}$ & Novem - & $\begin{array}{l}\text { Decem- } \\
\text { ber }\end{array}$ \\
\hline \multicolumn{13}{|c|}{1935 Base Perlod } \\
\hline 1947 & 112 & 10.9 & 109 & 109 & 109 & 111 & 112 & 112 & 115 & 111 & 116 & 120 \\
\hline 1948 & 120 & 110 & 113 & 112 & 110 & 112 & 114 & 108 & 10.3 & 115 & 116 & 119 \\
\hline 1949 & 118 & 114 & 113 & 122 & 113 & 121 & 12,4 & 126 & 117 & 116 & 117 & 120 \\
\hline 1950 & 121 & 116 & 116 & 114 & 115 & 118 & 118 & 118 & 121 & 122 & 122 & 121 \\
\hline 1951 & 114 & 12.2 & 124 & 125 & 12.2 & 12.6 & 125 & 12.4 & 126 & 129 & 128 & 134 \\
\hline 1952 & 13.4 & 129 & 130 & 127 & 127 & 13.0 & 132 & 130 & 13,3 & 13,3 & 134 & 139 \\
\hline 1953 & 13,6 & 13.3 & 131 & 129 & 129 & 14.2 & 135 & 13.3 & 13.4 & 13.5 & 136 & 139 \\
\hline 1954 & 140 & 13.4 & 134 & 133 & 13.6 & 142 & 14.6 & 138 & 137 & 140 & 143 & 146 \\
\hline 1955 & 143 & 140 & 13.8 & 139 & 138 & 139 & 14.0 & 139 & 140 & 140 & 141 & 145 \\
\hline 1956 & 143 & 139 & 140 & 139 & 139 & 142 & 14.1 & 14.0 & 142 & 141 & 144 & 14.8 \\
\hline 1957 & 14.5 & 14,1 & 141 & 141 & 14.0 & 142 & 143 & 141 & 142 & 142 & 142 & 148 \\
\hline 1958 & 146 & 148 & 14,9 & 14.8 & 147 & 149 & 15.0 & 14.9 & 14.9 & 14.8 & 150 & 155 \\
\hline 1959 & 15.2 & 149 & 147 & 149 & 149 & 149 & 151 & 150 & 150 & 15.1 & 151 & 156 \\
\hline 1960 & 154 & 148 & 146 & 147 & 148 & 149 & 15, & 15.2 & 153 & 15,3 & 156 & 16 \\
\hline 1961 & 161 & 156 & 155 & 155 & 15.6 & 15.8 & 15.8 & 159 & 160 & 162 & 165 & 168 \\
\hline 1962 & 16.9 & 161 & 16.2 & 163 & 165 & 165 & 167 & 166 & 167 & 175 & 170 & 176 \\
\hline 1963 & 175 & 169 & 169 & 17.0 & 171 & 171 & 174 & 172 & 174 & 175 & 176 & 185 \\
\hline 1964 & 183 & 176 & 176 & 177 & 176 & 180 & 10.1 & 180 & 18.4 & 184 & 18.5 & 192 \\
\hline 1965 & 19.2 & 187 & 18.7 & 189 & 189 & 192 & 193 & 19.2 & 193 & 19.5 & 196 & 204 \\
\hline 1966 & 20.4 & 198 & 19.8 & 201 & 200 & 199 & 20,2 & 19.9 & 20, & 20.2 & 203 & 20.9 \\
\hline 1967 & 210 & 209 & 210 & 20.9 & 209 & 212 & 214 & 213 & 217 & 21.8 & 22.0 & 22,5 \\
\hline 1968 & 228 & 223 & 222 & 223 & 223 & 224 & 227 & 227 & 226 & 23.1 & 232 & 240 \\
\hline 1969 & 244 & 23.5 & 231 & 23.3 & 23,4 & 233 & 231 & 23.2 & 233 & 233 & 235 & 242 \\
\hline 1970 & 24.6 & 238 & 233 & 23.8 & 237 & 23.8 & 24.1 & 24,2 & 249 & 250 & 250 & 25,9 \\
\hline 1971 & 267 & 259 & 258 & 25.9 & 264 & 264 & 267 & 26.7 & 270 & 26.9 & 272 & 27.8 \\
\hline 1972 & 28.9 & 27.7 & 27.7 & 28.2 & 28.4 & 28.5 & 29.2 & 29.0 & 289 & 295 & 29.8 & 30,6 \\
\hline
\end{tabular}

\section{Base Period}

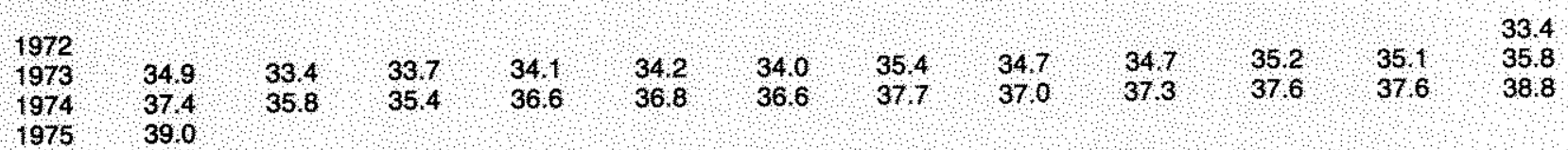

\section{Base Period}

\begin{tabular}{|c|c|c|c|c|c|c|c|c|c|c|c|c|}
\hline & 394 & 380 & 377 & 384 & 376 & 384 & 383 & 379 & 382 & 380 & 38.5 & 39,4 \\
\hline & 39,8 & 380 & 38,2 & 38,6 & 385 & 38.4 & 387 & 385 & 386 & 389 & 397 & 402 \\
\hline 977 & 418 & 392 & 39.6 & 40.2 & 401 & 4011 & 41,1 & 410 & 408 & 415 & 417 & 42.4 \\
\hline 1978 & 445 & 424 & 420 & 430 & 432 & 435 & 446 & 43,9 & 440 & 448 & 450 & 452 \\
\hline 1979 & 470 & $43 \mathrm{~g}$ & 435 & 443 & 440 & 441 & $45 \Omega$ & 447 & 449 & 464 & 461 & 478 \\
\hline 1980 & 48.8 & 461 & 46, & 457 & 452 & 459 & 472 & 472 & 48,1 & 486 & a & $\therefore$ \\
\hline
\end{tabular}


Table 2

Adjusted Bank Reserve, 1975 Base Period (billions of dollars, not seasonally adjusted)

\begin{tabular}{|c|c|c|c|c|c|c|c|c|c|c|c|c|}
\hline Year & Januany & $\begin{array}{l}\text { reb- } \\
\text { ruary }\end{array}$ & Mareh & April & May & June & Jaly & Alygust & Septem & $\begin{array}{l}\text { Oeto } \\
\text { per }\end{array}$ & $\begin{array}{l}\text { Novem- } \\
\text { ber }\end{array}$ & $\begin{array}{l}\text { Decen } \\
\text { ber }\end{array}$ \\
\hline 1947 & 123 & 120 & 12.0 & 12.0 & 12.0 & 121 & 123 & 124 & 127 & 128 & 128 & 132 \\
\hline 1948 & 131 & 121 & 124 & 123 & 120 & 123 & 125 & 119 & 113 & 127 & 128 & 130 \\
\hline 1949 & 30 & 126 & 12.4 & 13.4 & 12.4 & 13.3 & $13: 6$ & 138 & 129 & 128 & 129 & 132 \\
\hline 1950 & 133 & 128 & 127 & 126 & 12.7 & 130 & 130 & 129 & 13.3 & 134 & 134 & 13,3 \\
\hline 1951 & 126 & 134 & 136 & 138 & 134 & 138 & 137 & 137 & 139 & 142 & 141 & 147 \\
\hline 1952 & 147 & 142 & 143 & 14.0 & 140 & 143 & 14.5 & 14,3 & 14,6 & 14.6 & 147 & 15.3 \\
\hline 1953 & 150 & 14,6 & 14,4 & 142 & 141 & 156 & 149 & 146 & 148 & 148 & 150 & 15,3 \\
\hline 1954 & 154 & 147 & 147 & 146 & 149 & 156 & 60 & 152 & 151 & 154 & 158 & 160 \\
\hline 1955 & 158 & 15.4 & 152 & 153 & 152 & 153 & 154 & 153 & 15.3 & 5.4 & 15. & 160 \\
\hline 1956 & 157 & 15,3 & 154 & 15,3 & 153 & 156 & 15.5 & 5.4 & 156 & $+5,5$ & 158 & 16,3 \\
\hline 1957 & 159 & 15.5 & 15.5 & 15.5 & 154 & 15.6 & 157 & 155 & 156 & 15,6 & 156 & 163 \\
\hline 1958 & 160 & 16.3 & 16,4 & 163 & 16,1 & 164 & 165 & 16.4 & 164 & 163 & 165 & 170 \\
\hline 1959 & 167 & 163 & 162 & 16.4 & 16.4 & 164 & 166 & 16,5 & 165 & 16.6 & 166 & 171 \\
\hline 1960 & 16.9 & 163 & 16, & 16,1 & 163 & 16.4 & 16,6 & 167 & 168 & 168 & 172 & 177 \\
\hline 1961 & 177 & 17.2 & 770 & 171 & 17,1 & 17,3 & 174 & 175 & 176 & 178 & 101 & 185 \\
\hline 1962 & 185 & 177 & 178 & 79 & 181 & 18.2 & 183 & 18.2 & 184 & 193 & 107 & 193 \\
\hline 1963 & 193 & 18.6 & 185 & 187 & 88 & 189 & 192 & 189 & 191 & 192 & 193 & 2013 \\
\hline 1964 & 201 & 19,4 & 193 & 19.5 & 19.3 & 198 & 199 & 19.8 & 202 & 20.2 & 20,4 & 21,1 \\
\hline 1965 & 21, & 20,6 & 20.5 & 208 & 20.8 & 211 & 212 & 211 & 212 & 214 & 21,6 & 22,4 \\
\hline 1966 & 22,4 & 21,8 & 218 & 221 & 220 & 219 & 22,2 & 219 & 221 & 222 & 224 & 23,0 \\
\hline 1967 & 231 & 230 & 23,1 & 229 & 230 & 233 & 235 & 23,4 & 238 & 240 & 242 & 247 \\
\hline 1968 & 251 & 245 & 244 & 246 & 245 & 247 & 250 & 249 & 249 & 25.4 & 255 & 26.4 \\
\hline 1969 & 268 & 259 & 25.4 & 256 & 258 & 257 & 254 & 25, & 256 & 256 & 258 & 266 \\
\hline 1970 & 271 & 261 & 25,6 & 262 & 26,1 & 261 & 26.5 & 26.6 & 274 & 275 & 275 & 28.4 \\
\hline 1971 & 294 & 285 & 284 & 285 & 290 & 29.0 & 293 & 294 & 297 & 296 & 29, & 305 \\
\hline 1972 & 317 & 30,4 & 304 & 310 & 31.3 & 313 & 321 & 31,9 & 318 & 32,4 & 328 & 336 \\
\hline 1973 & 352 & 337 & 340 & 34,4 & 34.5 & 34,3 & 357 & 35,0 & 349 & 355 & 35,4 & 36,1 \\
\hline 1974 & 377 & 36,1 & 357 & 36,9 & 371 & 36.9 & 380 & 373 & 376 & $37 \%$ & 379 & 392 \\
\hline 1975 & 39.4 & 380 & 377 & 38,4 & 376 & 38.4 & 38.3 & 37.9 & 382 & 380 & 38.5 & 39.4 \\
\hline 1976 & 398 & 380 & 382 & 386 & 385 & 38.4 & 387 & 38.5 & 386 & 38.9 & 307 & 40,2 \\
\hline 1977 & 418 & 392 & 396 & 402 & 40,1 & 40.1 & 41,1 & 41,0 & 40.8 & 41.5 & 412 & 424 \\
\hline 1978 & 445 & 424 & 420 & 43,0 & 432 & 43.5 & 446 & 439 & 440 & 449 & 450 & 45,2 \\
\hline 1979 & 470 & 438 & 435 & 443 & 44.0 & 441 & 451 & 447 & 449 & 46.4 & 461 & 478 \\
\hline 1980 & 488 & 46,1 & 46,1 & 45.7 & 45.2 & 45.9 & 47.2 & 47.2 & 481 & 486 & $\square$ & $\because$ \\
\hline
\end{tabular}


Table 3

Adjusted Bank Reserves, 1975 Base Period (billions of dollars, seasonally adjusted)

\begin{tabular}{|c|c|c|c|c|c|c|c|c|c|c|c|c|}
\hline Year & Ianuery & $\begin{array}{l}\text { Heb- } \\
\text { Hady }\end{array}$ & Mareh & Aprll & May & June & ouly & August & Septem & $\begin{array}{l}\text { opto } \\
\text { ber }\end{array}$ & $\begin{array}{l}\text { Novem } \\
\text { ber }\end{array}$ & Decem \\
\hline 1947 & 120 & 122 & 12,2 & 122 & 12, & 121 & 12, & 126 & 127 & 127 & 127 & 129 \\
\hline 1948 & 128 & 123 & 126 & 125 & 123 & 12,3 & 124 & 121 & 114 & 126 & 127 & 127 \\
\hline 1949 & 126 & 127 & 126 & 137 & 127 & 13,3 & 135 & 140 & 129 & 127 & 128 & 128 \\
\hline 1950 & 129 & 130 & 129 & 128 & 129 & 129 & 129 & 13, & 133 & 13, & 13,3 & 13.0 \\
\hline 1951 & 12.2 & 135 & 138 & 141 & 137 & 138 & 137 & 138 & 139 & 14, & 140 & 143 \\
\hline 1952 & 144 & 143 & 145 & 143 & 143 & 143 & 14.4 & 14.5 & 146 & 145 & 146 & 148 \\
\hline 1953 & 146 & 147 & 14,6 & 145 & 144 & 15. & 149 & 148 & 148 & 148 & 149 & 148 \\
\hline 1954 & 151 & 148 & 149 & 149 & 152 & 155 & 160 & 153 & 15,1 & 154 & 156 & 155 \\
\hline 1955 & 15,5 & 156 & 15.4 & 155 & 15.5 & 152 & 154 & 15.5 & 15,4 & 155 & 15,4 & 15,4 \\
\hline 1956 & 15,4 & 155 & 15.6 & 155 & 155 & 156 & 15,5 & 15.5 & 157 & 15.6 & 157 & 158 \\
\hline 1957 & 156 & 15,6 & 157 & 157 & 156 & 156 & 157 & 156 & 157 & 157 & 15.5 & 157 \\
\hline 1958 & 157 & 164 & 166 & 164 & 16,3 & 165 & 165 & 16.5 & 16,4 & 16.4 & 16.4 & 16.5 \\
\hline 1959 & 164 & 165 & 16,4 & 16.6 & 166 & 16.5 & 16,6 & 166 & 165 & 166 & 16.5 & 16.6 \\
\hline 1960 & 165 & 164 & 16,4 & 163 & 165 & 16,5 & 161 & 168 & 169 & 169 & 171 & 171 \\
\hline 1961 & 172 & 173 & 173 & 173 & 17,3 & 175 & 174 & 176 & 177 & 178 & 180 & 179 \\
\hline 1962 & 180 & 179 & 18, & 82 & 18,3 & 183 & 183 & 184 & 185 & 103 & 18.6 & 187 \\
\hline 1963 & 187 & 187 & 188 & 189 & 190 & 190 & 192 & 191 & 192 & 192 & 103 & 197 \\
\hline 1964 & 196 & 19,5 & 196 & 196 & 19.5 & 199 & 19, & 200 & 20,4 & 20.3 & 204 & 205 \\
\hline 1965 & 20,5 & 207 & 208 & 20.9 & 210 & 213 & 212 & 214 & 213 & 215 & 216 & 218 \\
\hline 1966 & 218 & 218 & 220 & 222 & 222 & 221 & 223 & 222 & 223 & 222 & 22.4 & 22,4 \\
\hline 1967 & 224 & 230 & 233 & 231 & 232 & 234 & 236 & 237 & 240 & 24,1 & 242 & 24, \\
\hline 1968 & 242 & 245 & 247 & 247 & 247 & 249 & 250 & 252 & 250 & 25, & 25,5 & 25,8 \\
\hline 1969 & 259 & 258 & 257 & 257 & 260 & 259 & 25,5 & 257 & 257 & 257 & 25,9 & $2 \sigma_{1}$ \\
\hline 1970 & 260 & 261 & 259 & 26,4 & 263 & 26,4 & 265 & 26, & 275 & 276 & 276 & 279 \\
\hline 1971 & 282 & 28,5 & 281 & 286 & 291 & 293 & 29,4 & 296 & 299 & 290 & 30,1 & 30,1 \\
\hline 1972 & 304 & 305 & 308 & 31,1 & 314 & 317 & 320 & 32.2 & 320 & 326 & 33,0 & 332 \\
\hline 1973 & 337 & 339 & 34,4 & 34,4 & 346 & 347 & 356 & 35,3 & 352 & 357 & 356 & 356 \\
\hline 1974 & 36.2 & 363 & 361 & $36 \Omega$ & 372 & 373 & $37 \mathrm{~s}$ & 377 & 379 & 361 & 381 & 38.5 \\
\hline 1975 & 378 & 384 & 38,1 & 38.4 & 377 & 38,8 & 382 & 382 & 385 & 382 & 38,6 & 387 \\
\hline 1976 & 38,3 & 38,4 & 387 & 38.5 & 38,6 & 38,9 & 385 & 389 & 389 & 39, & 399 & 39.4 \\
\hline 1977 & 402 & 396 & 40,0 & 40.2 & 40,3 & 40,5 & 410 & 414 & 412 & 418 & 4,6 & 416 \\
\hline 1978 & 424 & 429 & 426 & 430 & 435 & 43,9 & 445 & 443 & 44,5 & 45,1 & 449 & 448 \\
\hline 1979 & 447 & 445 & 443 & 44.5 & 44,4 & 44,6 & 449 & 45,1 & 45,4 & 46,3 & $46: 0$ & 47,2 \\
\hline 1980 & 46,3 & 468 & 469 & 459 & 457 & 46,5 & 470 & 475 & 486 & 48.4 & - & $\square$ \\
\hline
\end{tabular}

